\title{
Multifunctional Isosteric Pyridine Analogs-Based 2-Aminothiazole: Design, Synthesis, and Potential Phosphodiesterase-5 Inhibitory Activity
}

\author{
Abdel Haleem M. Hussein ${ }^{1}$, Ahmed A. Khames ${ }^{1}{ }^{(D}$, Abu-Bakr A. El-Adasy $^{1}$, Ahmed A. Atalla ${ }^{1}$, \\ Mohamed Abdel-Rady ${ }^{2}$, Mohamed I. A. Hassan ${ }^{3}$, Mahrous A. Abou-Salim ${ }^{4}$, Yaseen A. M. M. Elshaier ${ }^{5, *}$ \\ and Assem Barakat 6,7,*(D)
}

Citation: Hussein, A.H.M.; Khames, A.A.; El-Adasy, A.-B.A.; Atalla, A.A.; Abdel-Rady, M.; Hassan, M.I.A.; Abou-Salim, M.A.; Elshaier, Y.A.M.M.; Barakat, A. Multifunctional Isosteric Pyridine Analogs-Based 2-Aminothiazole: Design, Synthesis, and Potential Phosphodiesterase-5 Inhibitory Activity. Molecules 2021, 26, 902. https://doi.org/10.3390/ molecules26040902

Academic Editor: Maria-João R. P. Queiroz

Received: 27 December 2020

Accepted: 2 February 2021

Published: 9 February 2021

Publisher's Note: MDPI stays neutral with regard to jurisdictional claims in published maps and institutional affiliations.

Copyright: (C) 2021 by the authors Licensee MDPI, Basel, Switzerland This article is an open access article distributed under the terms and conditions of the Creative Commons Attribution (CC BY) license (https:// creativecommons.org/licenses/by/ $4.0 /)$
1 Department of Chemistry, Faculty of Science, Al-Azhar University, Assiut 71524, Egypt; abdelhaleemmh@yahoo.com (A.H.M.H.); a.khames@yahoo.com (A.A.K.); a_eladasy@azhar.edu.eg (A.-B.A.E.-A.); ahmedswify54@yahoo.com (A.A.A.)

2 Department of Chemistry, Faculty of Science, Assiut University, Assiut 71516, Egypt; mohamedrady2004@yahoo.com

3 Department of Pharmacology \& Toxicology, Faculty of Pharmacy, Al-Azhar University, Assiut 71524, Egypt; mohamed_aa74@yahoo.com

4 Department of Pharmaceutical Organic Chemistry, Faculty of Pharmacy, Al-Azhar University, Assiut 71524, Egypt; mahrousabousalim@azhar.edu.eg

5 Department of Organic and Medicinal Chemistry, Faculty of Pharmacy, University of Sadat City, Menoufiya 32958, Egypt

6 Department of Chemistry, College of Science, King Saud University, P.O. Box 2455, Riyadh 11451, Saudi Arabia

7 Department of Chemistry, Faculty of Science, Alexandria University, Alexandria 21321, Egypt

* Correspondence: yaseen.elshaier@fop.usc.edu.eg (Y.A.M.M.E.); ambarakat@ksu.edu.sa (A.B.)

Abstract: The elaboration of new small molecules that target phosphodiesterase enzymes (PDEs), especially those of type 5 (PDE5), is an interesting and emerging topic nowadays. A new series of heterocycle-based aminothiazoles were designed and synthesized from the key intermediate, 3-oxo-N-(thiazol-2-yl)butanamide (a PDE5 inhibitor that retains its amidic function), as an essential pharmacophoric moiety. The PDE5 inhibitors prevent the degradation of cyclic guanosine monophosphate, thereby causing severe hypotension as a marked side effect. Hence, an in vivo testing of the target compounds was conducted to verify its relation with arterial blood pressure. Utilizing sildenafil as the reference drug, Compounds 5, 10a, and $\mathbf{1 1} \mathbf{b}$ achieved $100 \%$ inhibitions of PDE5 without significantly lowering the mean arterial blood pressures $(115.95 \pm 2.91,110.3 \pm 2.84$, and $78.3 \pm 2.57$, respectively). The molecular docking study revealed that the tested compounds exhibited docking poses that were similar to that of sildenafil (exploiting the amide functionality that interacted with GLN:817:A). The molecular shape and electrostatic similarity revealed a comparable physically achievable electrostatic potential with the reference drug, sildenafil. Therefore, these concomitant results revealed that the tested compounds exerted sildenafil-like inhibitory effects (although without its known drawbacks) on blood circulation, thus suggesting that the tested compounds might represent a cornerstone of beneficial drug candidates for the safe treatment for erectile dysfunction.

Keywords: 2-aminothiazoles; phosphodiesterase 5; sildenafil; erectile dysfunction; docking; OpenEye

\section{Introduction}

Erectile dysfunction (ED) is the persistent inability to achieve or maintain a penile erection that is sufficient for sexual performance [1]. The first-line treatment of ED patients involves the oral administration of phosphodiesterase type 5 inhibitors (PDE5), such as sildenafil [2], vardenafil [3], tadalafil [3], and the recent avanafil [4] (Figure 1), which hydrolyze cyclic guanosine monophosphate (cGMP) to GMP [5,6]. However, most of the patients experienced many side effects, including headache, blurred vision, facial flushing, 
and back pain [2-4], as well as severe hypotension. Sildenafil produces hypotension effect via its capability in inhibition of phosphodiesterase enzymes leading to the accumulation of cGMP that produces hypotension effect [3,4]. Among the drugs, sildenafil, which is a selective PDE5 inhibitor, possesses the following characteristic pharmacophoric features (Figure 1) (a) The lactam functionality of the pyrimidinone moiety, which forms hydrogen bond with the amino acid, GLN:817:A; (b) the pyrzolo[4,3-d]pyrimidine core, which exhibits a hydrophobic interaction with the amino acids, Val-782, Tyr-612, and Phe-820, in the binding pocket; and (c) the ethoxyphenyl group that fits into the hydrophobic pocket that was formed by the amino acids, Phe-786, Ala-783, Leu-804, and Val-782 [2,7]. Moreover, a second-generation selective PDE5 inhibitor, avanafil, possesses two hydrogen bonds with GLN:817:A and GLN:775:A, as well as a halogen bond with a backbone carbonyl oxygen (ALA:779:A) of an adjacent $\alpha$-helix. These binding properties contribute to the inhibitory potency and illustrate the feasibility of exploiting the $\alpha$-helix backbone in the structure-based drug design with the target PDE5-inhibitory molecules.<smiles>CCCc1nn(C)c2c(=O)[nH]c(-c3cc([N+](=O)[O-])ccc3OCC)nc12</smiles>

(First generation)<smiles>CCCc1nc(C)c2c(=O)[nH]c(-c3cc(OCC)ccc3OS(=O)(=O)[O-])nn12</smiles>

denafil<smiles>CN1CC(=O)N2C(=O)CN(C)[C@H](c3ccc4c(c3)OCO4)c3[nH]c4ccccc4c3C2C1</smiles>

Tadalafil<smiles>COc1ccc(CNc2nc(N3CCC[C@H]3CO)ncc2C(=O)NCc2ncccn2)cc1Cl</smiles>

Avanafil

(Second generation)

Figure 1. PDE5 inhibitors.

Conversely, the 2-aminothiazole-based heterocycles have attracted increased interest in the fields of drug design and discovery because of their effectiveness as small molecular drug candidates [8,9]. They are considered as a cornerstone for synthesizing many compounds with diverse pharmacological applications, such as anticancer [8-12], antibacterial [13,14], anti-inflammatory [15-17], antileishmanial [18], and influenza neuraminidase inhibitors [19], as well as PDE5 regulators and cyclooxygenases 1 and 2 (COX-1/COX-2) inhibitors [20].

Therefore, the development of new PDE5 inhibitors, which guarantees the adequate safety of the circulatory-system, is still a challenge for many medicinal chemists. The design of these compounds was elaborated by keeping the most important pharmacophores especially amide functionality aiming to get more selective PDE5 inhibitors. Based on our previous studies [7], we envisioned the design and synthesis of new derivatives of PDE5 inhibitors possessing the characteristic features of the first and second generations to treat ED without affecting the blood pressure. Therefore, the design strategy was developed to synthesize different heterocyclic ring-based 2-aminothiazole motifs by exploiting the essential pharmacophoric features of PDE5I [21,22], such as (1) a heterocyclic scaffold, namely the thiazole ring; (2) the amidic part to form essential HBs with GLN:817:A; and (3) the aryl part containing the polar substituents (Figure 2). 


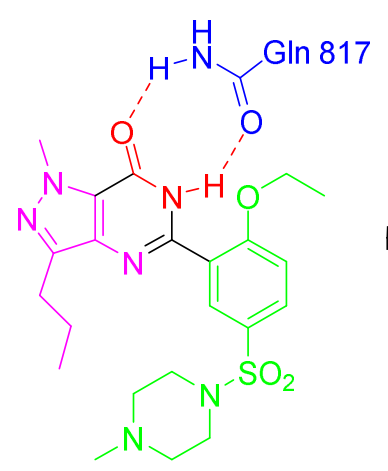

Sildenafil

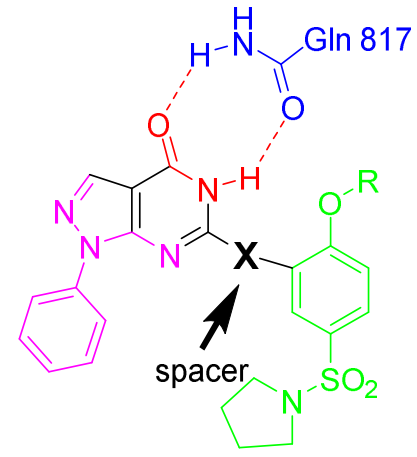

$\mathrm{X}=\mathrm{CH}=\mathrm{CH}, \mathrm{CH}_{2} \mathrm{O}, \mathrm{CH}_{2} \mathrm{NH}^{-}$ our previous work<smiles>CCCc1nn(C)c2c(=O)n(CCNC(=O)Cc3ccccc3)c(-c3cc([S+](=O)(=O)N4CCN(C)CC4)ccc3OCC)nc12</smiles>

Sildenafil

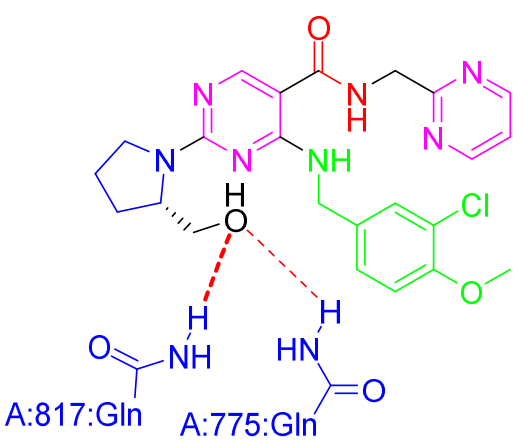

Avanafil (Second generation)<smiles>[X]C1=CCCCN1c1nccs1</smiles>

I<smiles>[X]C(=O)CC(CC)Nc1nccs1</smiles>

II<smiles>O=C(Nc1nccs1)C1CCCCC1</smiles>

II

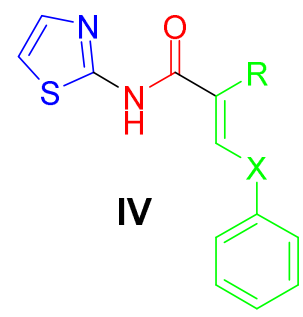

\section{Current study}

Figure 2. Medicinal chemistry design of current study.

\section{Results}

\subsection{Chemistry}

The reactions of $\mathbf{1}$ [23] with different active methylene reagents were investigated. Thus, 1 reacted with malononitrile in ethanolic piperidine to yield the pyridine derivative, $\mathbf{2}$, as the only isolated product. Additionally, 1 reacted with cyanothioacetamide under the same experimental conditions to yield the pyridinethione derivative, 3 , in a quantitative yield rather than pyridine (4). The structure of 3 was elucidated by different spectroscopic techniques, as follows: the IR data revealed a nitrile functionality at $v=2247 \mathrm{~cm}^{-1},{ }^{13} \mathrm{C}$ NMR revealed a peak at $\delta 119.17 \mathrm{ppm}$, and ${ }^{1} \mathrm{H}$ NMR revealed two NH groups at $\delta 8.70$ and $12.58 \mathrm{ppm}$. Other elemental analyses were also conducted. Conversely, 1 reacted with acrylonitrile under reflux with pyridine to yield the tetrahydropyridone derivative, 5 (Scheme 1). 


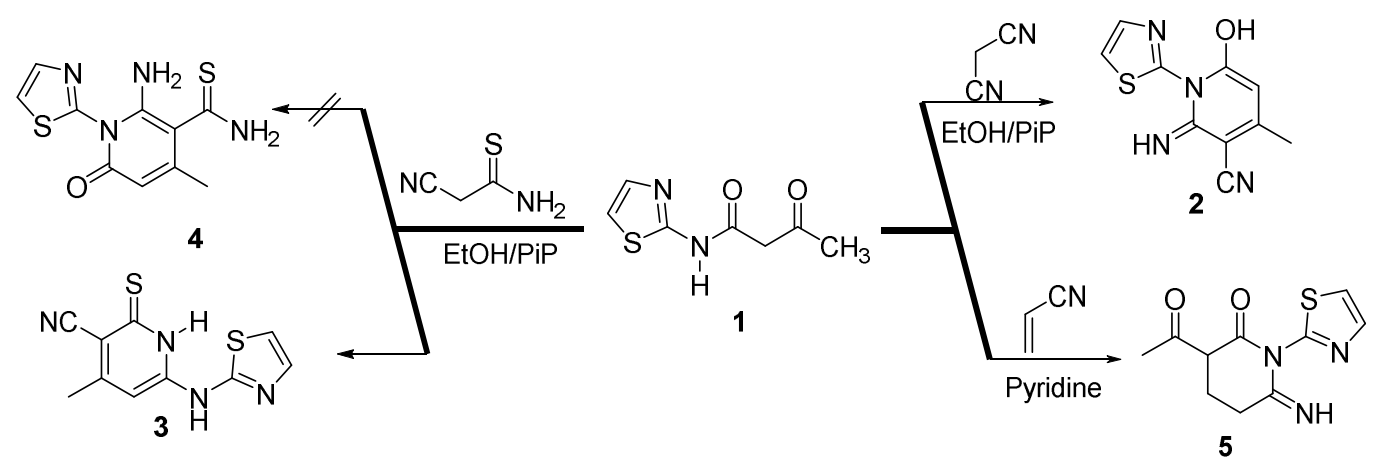

Scheme 1. Synthetic routes for the 2, 3, and 5.

Table 1 shows the aromatic diazonium salt as a route to new azines and condensed azines with potential activities. Therefore, $\mathbf{1}$ coupled smoothly with the aromatic diazonium salt to yield the corresponding arylhydrazones, $\mathbf{6 a}-\mathbf{c}$ in good yield [24]. However, the condensation of 1 with the aromatic aldehydes in a basic medium afforded the arylidine derivatives, $\mathbf{7 a}, \mathbf{b}$ [25]. Moreover, $\mathbf{1}$ reacted with a mixture of aromatic aldehydes, such as $p$ florobenzaldehyde, $p$-anisaldehyde, and thiourea to yield the expected pyrimidine thiones, $\mathbf{8 a}, \mathbf{b}$ [26]. Similarly, $\mathbf{1}$ reacted with a mixture of terphthaldehyde and thiourea to afford the bis-structure, 9 , which was confirmed according to its compatible spectroscopic data. The condensation reaction of $\mathbf{1}$ with malononitrile/ethylcyanoacetate and elemental sulfur under reflux in ethanol/morpholine afforded the thiophene derivatives, 10a,b (Scheme 2).

Table 1. Effect of tested compounds on PDE5 $\left(10^{4} \mathrm{nM}\right)$ and MABP.

\begin{tabular}{|c|c|c|}
\hline Compound No. & $\begin{array}{c}\text { PDE5 } \\
\text { (Inhibition \%) }\end{array}$ & МАВР \\
\hline 1 & 13 & $103.1 \pm 1.85^{\#}$ \\
\hline 2 & 100 & 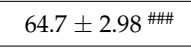 \\
\hline 3 & 2 & $79.3 \pm 2.57$ \#\# \\
\hline 5 & 100 & $115.95 \pm 2.91$ \\
\hline $6 a$ & 20 & $110.1 \pm 3.5^{\# \#}$ \\
\hline $6 c$ & 5 & $108.8 \pm 3.9^{\#}$ \\
\hline $7 a$ & 38 & $87.2 \pm 2.68^{*}$ \\
\hline $7 \mathrm{~b}$ & 62 & $90.4 \pm 2.84^{* *}$ \\
\hline $8 b$ & 23 & $88.1 \pm 1.62$ ** \\
\hline 9 & 10 & $90.1 \pm 1.62 * *$ \\
\hline $10 a$ & 100 & $110.3 \pm 2.84^{\#}$ \\
\hline $10 \mathrm{~b}$ & 82 & $105.3 \pm 2.84^{\#}$ \\
\hline $11 a$ & 8 & $120.1 \pm 2.96^{\# \# \#}$ \\
\hline $11 \mathrm{~b}$ & 100 & $78.3 \pm 2.57$ \\
\hline 12 & 7 & $90.3 \pm 1.43 * *$ \\
\hline 11c & 13 & $81.3 \pm 2.57$ \#\# \\
\hline 13 & 8 & $81.10 \pm 3.78^{\#}$ \\
\hline Control & - & $93.10 \pm 1.55$ \\
\hline Nitroprusside & - & $52.10 \pm 1.11^{\# \# \#}$ \\
\hline Sildenafil & 100 & $72.50 \pm 2.92^{\# \#}$ \\
\hline
\end{tabular}

Data were expressed as means \pm SE $(n=4)$. Multiple comparisons were done using one-way ANOVA followed by Tukey-Kramer as post-ANOVA test. \#: significantly different from control group at $p<0.05$. \#\#: significantly different from control group at $p<0.05$. \#\#\#: significantly different from control group at $p<0.05 .{ }^{*}$ : significantly different from sildenafil group at $p<0.05{ }^{* *}$ : significantly different from sildenafil group at $p<0.05$.

Moreover, compounds 6a-c were condensed with DMF-DMA to yield the pyridazinones, 11a-c, in excellent yield. The reflux of 11c with hydrazine hydrate in pyridine afforded 12, while its treatment with phenylhydrazine under solvent-free conditions yielded 13 (Scheme 3). 


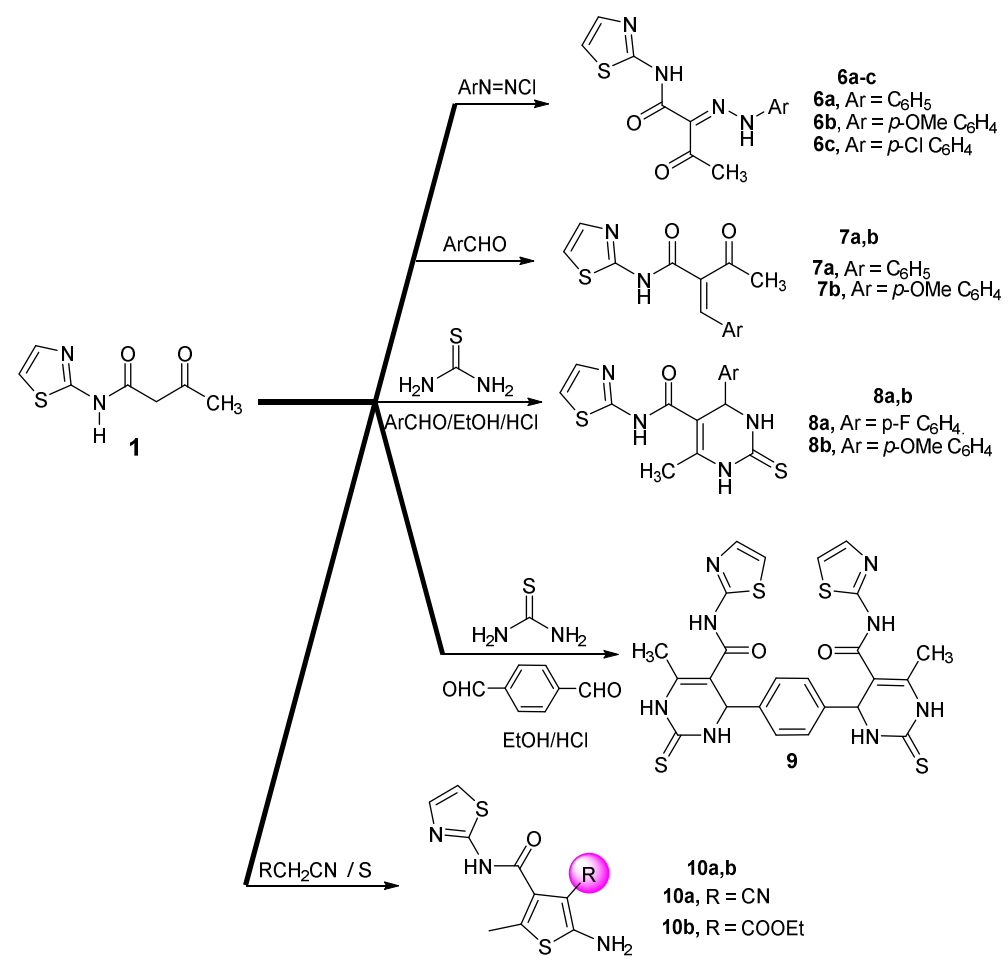

Scheme 2. Synthetic routes for the compounds 6-10.

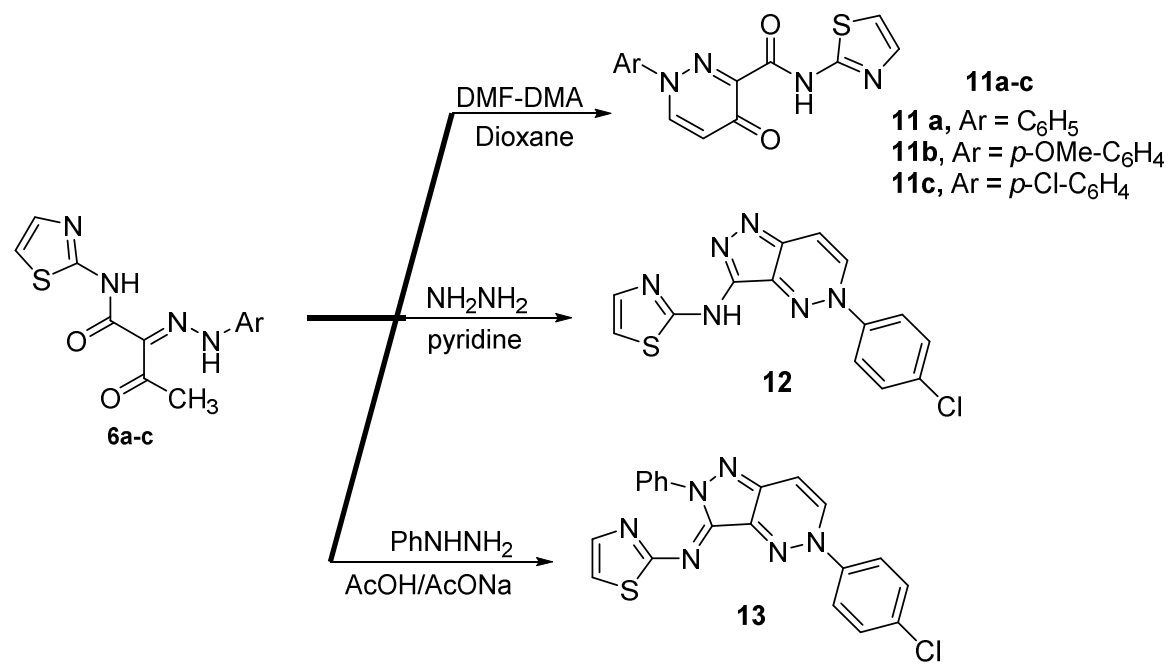

Scheme 3. Synthetic routes for the compounds $\mathbf{1 2}$ and 13.

\subsection{In Vitro PDE5 Inhibitory Activity Assay}

As presented in Table 1, the synthesized compounds were tested for their in vitro PDE5 inhibitory activity employing sildenafil as a reference drug at a concentration of $10^{4} \mathrm{nM}$ [27]. As indicated by the results, the tested compounds were classified into three main groups based on their inhibitory activities: $2,5, \mathbf{1 0 a}, \mathbf{b}$, and $\mathbf{1 1 b}(82 \%)$ completely inhibited PDE5 (100\%) compared to sildenafil, while $\mathbf{7 a}, \mathbf{b}$ exhibited moderate activities ( $38 \%$ and $62 \%$, respectively). Furthermore, $\mathbf{3}, \mathbf{6 b}, \mathbf{c}, \mathbf{8 b}, \mathbf{1 1} \mathbf{c}, \mathbf{1 2}$, and $\mathbf{1 3}$ were tested, and they demonstrated weak inhibitory activities against PDE5.

\subsection{Pharmacology}

The PDE5 inhibitors potentiated the effect of NO by preventing the degradation of cGMP, thereby enhancing vasodilation and increasing blood flow, although with severe 
hypotension as a marked side effect. Hence, the target compounds were not subjected to in vivo testing to verify the existence of any effect on MABP, and the data of the vasorelaxant effects of the tested compounds are presented in Table 1. The data revealed that the MABP values of all the compounds except 2 are higher than those of nitroprusside and sildenafil. Compound 2 values concerning its effect on MABP are less than that of sildenafil, and more than that of nitroprusside (Table 1 ).

Compounds 1, 6, 11b, 10a,b, 5, and $\mathbf{6 c}$ significantly increased MABP in the control rabbits (Table 1). Compounds $\mathbf{9}, \mathbf{8 b}, \mathbf{1 2}, \mathbf{7 a}, \mathbf{b}$ did not exert any significant difference from those of the control, but their MABP values were still significantly higher than that of sildenafil (Table 1). Compounds $\mathbf{9}, \mathbf{8} \mathbf{b}, \mathbf{1 2}, \mathbf{7 a}, \mathbf{b}$ did not reveal any significant difference from the control regarding their effects on MABP, but there was a significant difference from the effect of sildenafil, where their values are markedly higher (Table 1). Compounds $\mathbf{1 1} \mathbf{b}, \mathbf{1 3}, \mathbf{2}$, 12, and 3 significantly lowered MABP compared with the control, but their values were still higher than that of sildenafil, although non-significantly (Table 1). Compounds $\mathbf{2}$ and $\mathbf{1 1} \mathbf{b}$ exhibited great correlation in their inhibitory actions on PDE5 and their effects on MABP.

Surprisingly, 5, 10a, $\mathbf{b}$, and $\mathbf{1 1} \mathbf{b}$ completely inhibited PDE5 without severe hypotension, while 2 inhibited PDE5 (100\%), although severe hypotension was observed. Regarding compounds 2, 5, 10a, and 11b, all of them inhibit phosphodiesterase 5 enzyme by $100 \%$. Compound 2 illustrated lowering in the mean arterial blood pressure (MABP) to a level less than that produced by sildenafil. Compound $\mathbf{1 1 b}$ reduced the MABP to a level higher than that produced by sildenafil. Finally, compounds $\mathbf{1 0 a}$, and $\mathbf{5}$ increased the MABP, both of them can be used in erectile dysfunction accompanied with hypotension. Accordingly, these compounds in addition to their effects on PDE5, have another action on blood pressure. The contrasting effect of compound 2 could be due to it rigidity and the ability of its amide bond and or pyridine moiety to form stronger HB. Generally, these results suggest the promising therapeutic roles of $\mathbf{5 , 1 0 a , b}$, and $\mathbf{1 1} \mathbf{b}$ in treating ED without hypotension (the serious side effect that limits the utilization of PDE5 inhibitors). This merit might be related to the pharmacophoric structural features, especially that in which the thiazole moiety was endowed with either pyridazine or the thiophene heterocycles through an amide bridge, thus confirming their shape and electrostatic similarities with sildenafil.

Interestingly, the common properties of the most active compounds are due to the following features: (a) the amide that is attached to thiazole; (b) the heterocyclic rings that are tethered to thiazole, such as the pyrimidine ring (responsible for the unfavorable results), pyridazine or pyridine moieties (responsible for the good interactions); and (c) the unsubstituted aryl group. Tethering the aryl ring with an electron-donating group (EDG) is better than with an electron-withdrawing group. Hence, the tethering of the thiazole moiety with a multifunctional heterocyclic ring (piperidine, pyridazine, or thiophene) through an amide bridge along with an EDG aryl group could improve the inhibitory activity without the dangerous effect on the blood pressure.

\subsection{Molecular Modeling}

\subsubsection{Lead Optimization by Scaffold Hopping}

Then molecular shape and electrostatic similarity were determined by the OpenEye EON scientific software by replacing all the molecules with the reference drug (sildenafil) to ensure physically realistic electrostatic potential comparisons [28]. The results revealed that the designed compounds possessed similar shapes and electrostatic potentials to sildenafil as shown in Figures S1-S3 (supplemental information). This conclusion was resolved based on the high EON-ET-Combo score, which is a beneficial score that considers the shape and electrostatic matches (the closest in the biological activity, as presented in Table 2). 
Table 2. The OpenEyes's EON scores of target compounds against sildenafil as a reference drug.

\begin{tabular}{|c|c|c|}
\hline Compound No. & EON ET Combo & EON Rank \\
\hline Sildenafil & 0.494 & 1 \\
\hline 9 & 0.370 & 2 \\
\hline 5 & 0.298 & 3 \\
\hline $6 a$ & 0.290 & 4 \\
\hline 12 & 0.247 & 5 \\
\hline $8 a$ & 0.235 & 6 \\
\hline 13 & 0.234 & 7 \\
\hline $6 b$ & 0.203 & 8 \\
\hline $11 b$ & 0.198 & 9 \\
\hline $11 a$ & 0.186 & 10 \\
\hline $8 b$ & 0.181 & 11 \\
\hline $6 c$ & 0.167 & 12 \\
\hline $7 a$ & 0.147 & 13 \\
\hline $7 \mathrm{~b}$ & 0.136 & 14 \\
\hline 2 & 0.129 & 15 \\
\hline 11c & 0.115 & 16 \\
\hline $10 a$ & 0.107 & 17 \\
\hline $10 \mathrm{~b}$ & 0.106 & 18 \\
\hline 3 & 0.041 & 19 \\
\hline
\end{tabular}

\subsubsection{Structure-Based Lead Discovery}

The designed synthesized compounds were docked into PDE5 with PDB ID, 2H42 [29]. To validate our study, the docking protocol commenced with sildenafil (the standard ligand that was co-crystallized with 2H42). The designed compounds were first subjected to a filtering process employing the OpenEye filter application [30], which functions by calculating the properties, such as $\mathrm{MW}, \mathrm{X} \log \mathrm{P}, \mathrm{X} \operatorname{logS}, \mathrm{PSA}$, hydrogen-bond donor and acceptor counts, rotatable bonds, ring size, and number, etc. Moreover, the filtering process assigns a graph-based protonation state for consistency and speed and offers ADME filters, such as Lipinski, Egan, Veber, and Martin. The compounds with impossible bonding and inappropriate elements were removed. Thereafter, the library was processed by the OpenEye Omega application in which the 3D conformations of the molecules were generated. Next, the OpenEye docking was performed with the FRED application [31,32].

The FRED-3.5.0.4 2020-released OpenEye docking application employs chemgauss4 as the state-of-the-art scoring function, which is the total score of both the favorable (shape, hydrogen bonding, and metal chelation) and unfavorable (desolvation and clash) interactions. The comparative FRED chemgauss 4 scores of the top-scoring synthesized compounds are depicted in Table 3 (the lower the score, the better the binding affinity) and are shown in Figures S4-S15 (supplemental information). The standard drug, sildenafil, featured hydrophobic-hydrophobic interactions, and it possesses two hydrogen bonds with GLN:817:A through the pyrimidine $\mathrm{NH}$ (bond length $=1.92 \AA$ ) and carbonyl (bond length $=2.16 \AA$ ) groups (Figure $3 \AA$ ). This mode of interaction is similar to its reported docking [29]. Generally, 3, $\mathbf{7 a}, \mathbf{8 b}$, and 11a overlaid in that same pane of sildenafil with the formation of two hydrogen bonds with GLN:817:A, while 2, 10a, 11b, and 11c each formed a hydrogen bond with GLN:817:A (Figure 3B,C, respectively). Compound $7 \mathbf{b}$ possessed a hydrogen bond with GLN:817:A, while $\mathbf{1 0 b}$ and 8a did not, although they all displayed in their various pane. Interestingly, the tested biologically active compounds, especially those that achieved $100 \%$ inhibition of PDE5, interacted with the receptor in a similar mode as did sildenafil (they formed HB of higher energy with GLN:817:A). Regarding 10a, it interacted with the receptor through the formations of two HBs: one was formed from the interaction of the nitrile group with GLN:817:A (bond length $=1.59 \AA$ ), while the second one with lower energy was formed between the amino group and TYR:612:A (bond length $=2.46 \AA$ ) (Figure 3D). Regarding 11b, it formed HB between the pyridazine 
carbonyl group and the amino group of GLN:817:A (bond length = 1.84 $\AA$ ) (Figure 3E). The detailed docking results are reported in the Supplementary Materials.
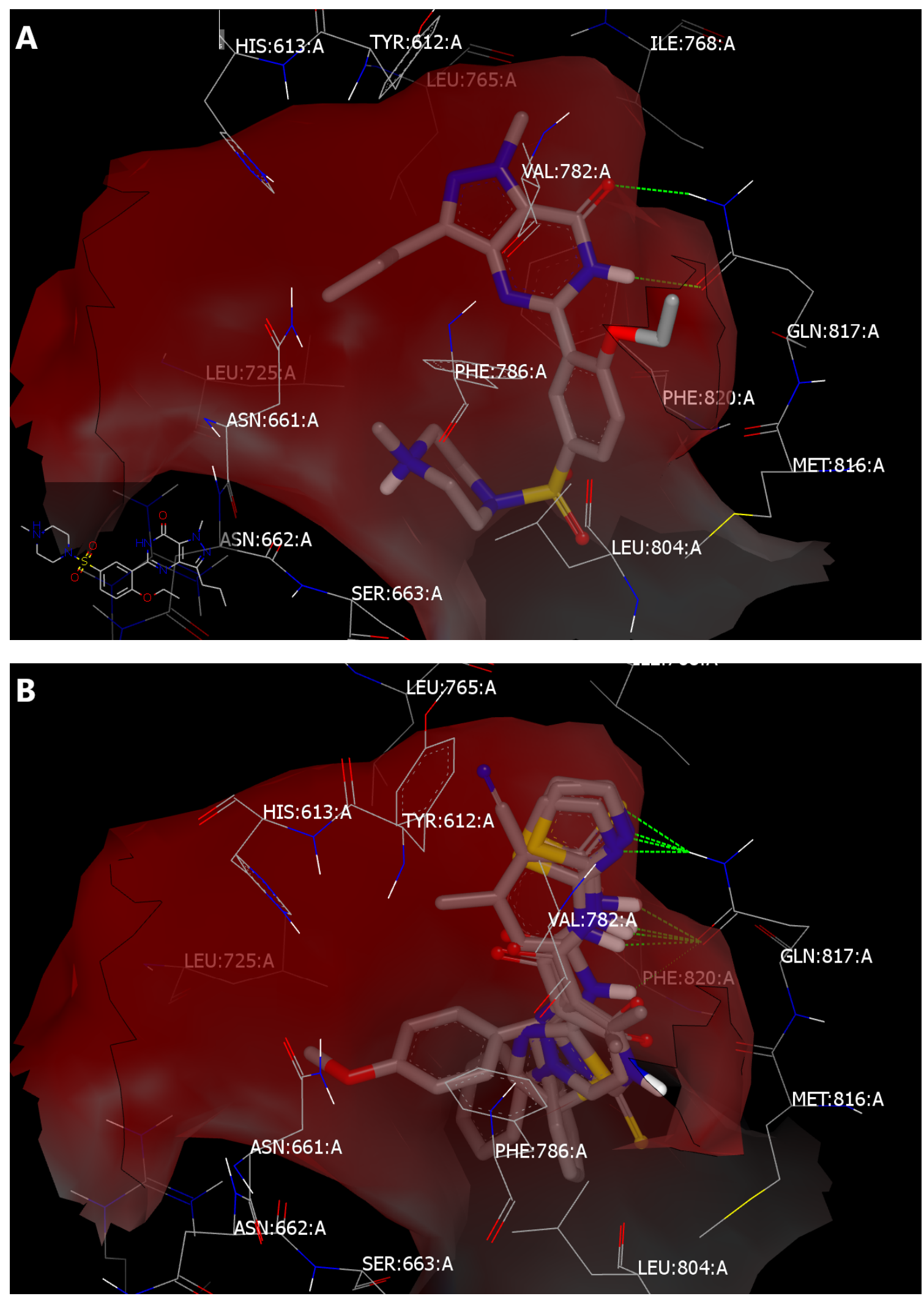

Figure 3. Cont. 

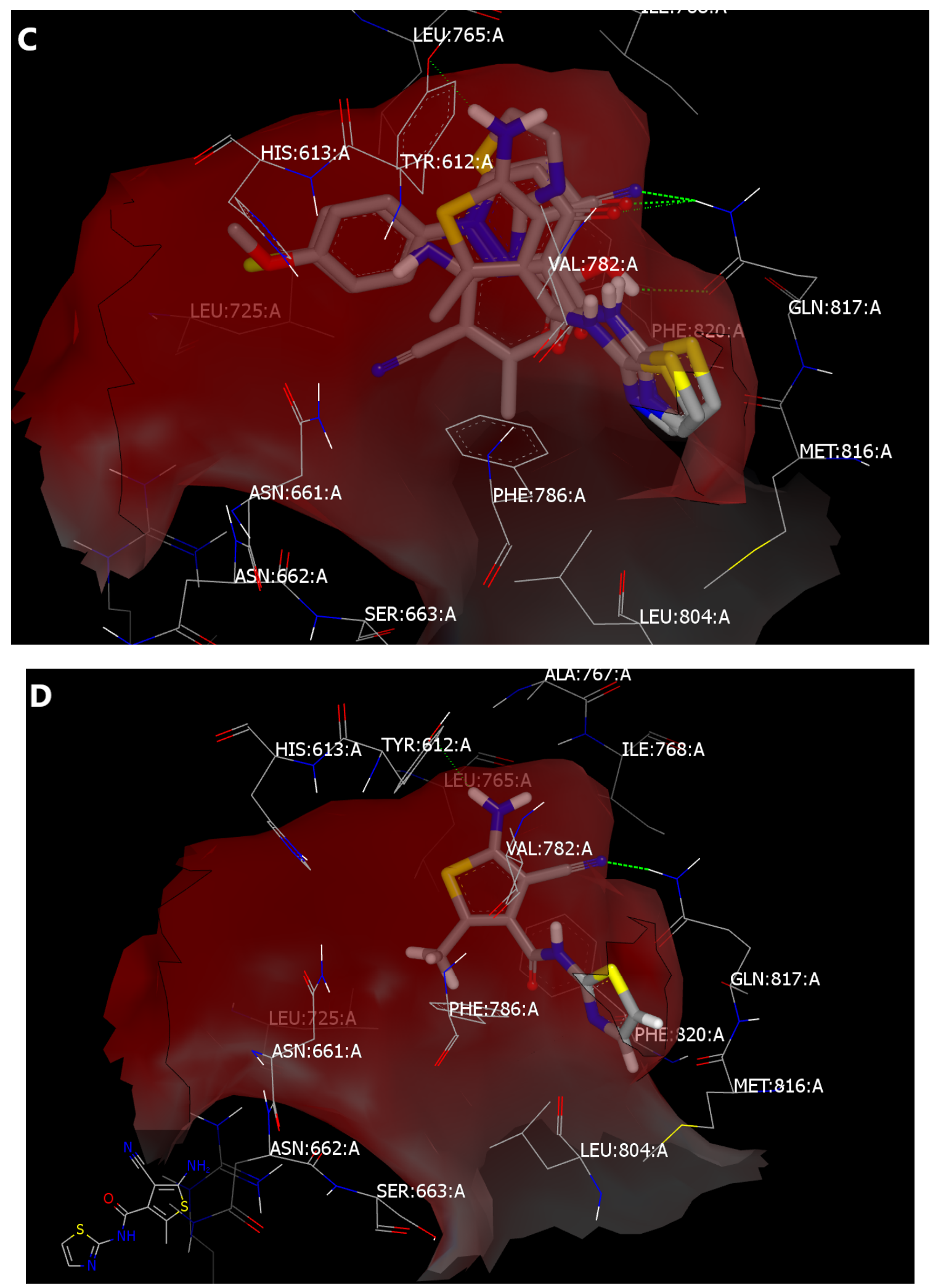

Figure 3. Cont. 


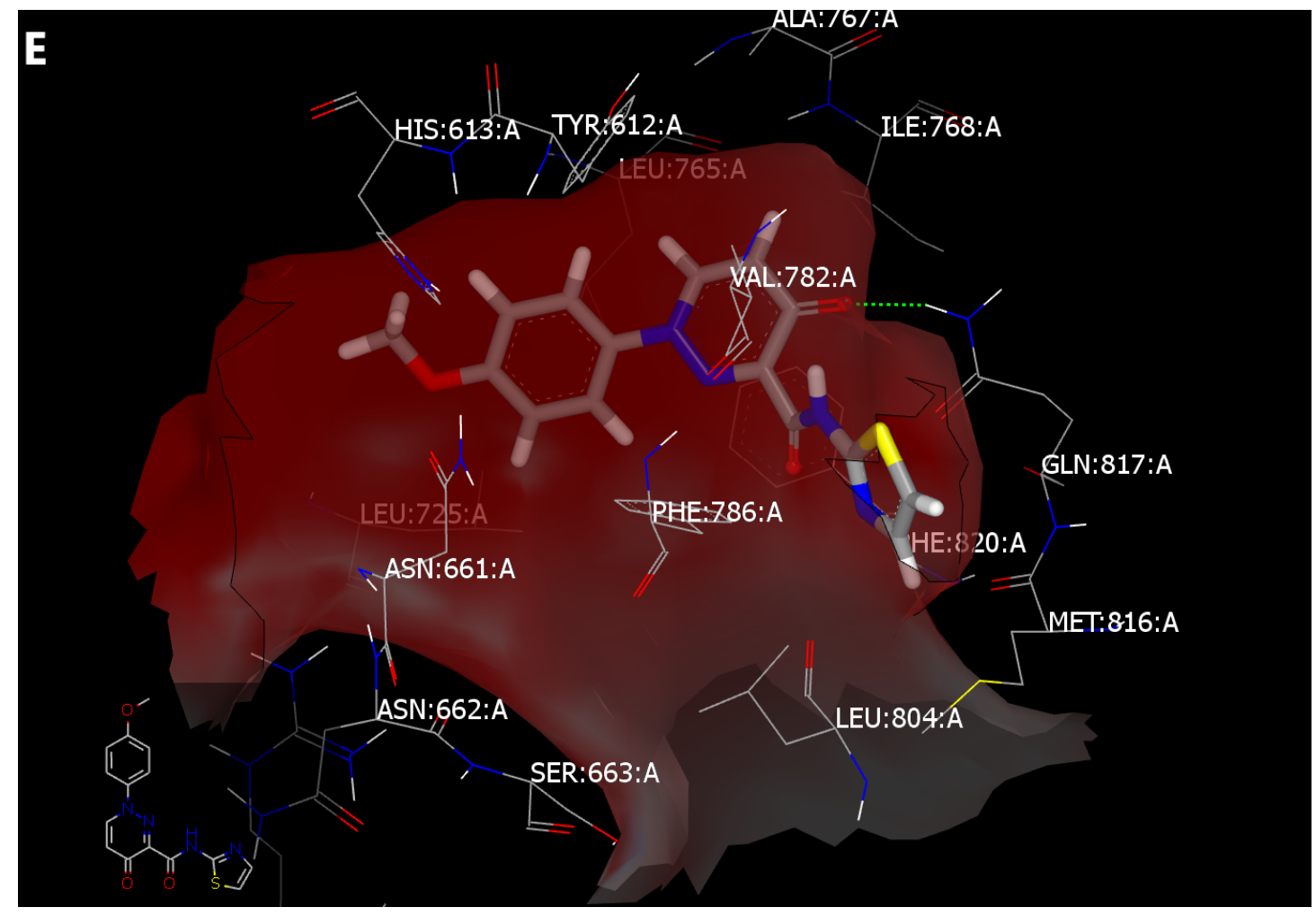

Figure 3. (A) Sildenafil docked with PDB ID: 2H42 with formation of two HBs and hydrophobic-hydrophobic interaction; (B) overlay of compounds $3,7 \mathbf{a}, \mathbf{8 b}$, and 11a in the same pane of sildenafil with formation of two HBs with GLN:817:A; (C) overlay of compounds 2, 10a, 11b,c with the formation of one HB with GLN:817:A; (D) compound 10a forms two HBs with GLN:817:A and TYR:612:A in addition to hydrophobic-hydrophobic interaction; (E) compound 11b forms one HB with GLN:817:A in addition to hydrophobic-hydrophobic interaction.

Although 5 was not processed for docking because it was filtered out in the Omega process because of some differences in its physicochemical properties, it was subjected to laboratory testing, where it revealed 100\% inhibition of PDE5.

Table 3. FRED Chemgauss4 scores for the docked compounds.

\begin{tabular}{cc}
\hline Comp. No & FRED Chemgauss4 Score \\
\hline $\mathbf{1 2}$ & -12.9335 \\
\hline $\mathbf{3}$ & -12.3931 \\
\hline $\mathbf{1 1 b}$ & -11.3665 \\
\hline $\mathbf{8 b}$ & -11.1262 \\
\hline $\mathbf{1 1 c}$ & -11.0972 \\
\hline $\mathbf{1 1 a}$ & -10.9461 \\
\hline $\mathbf{7 a}$ & -10.9088 \\
\hline $\mathbf{1 0 b}$ & -10.1529 \\
\hline $\mathbf{8 a}$ & -9.7921 \\
\hline $\mathbf{1 0 a}$ & -9.594 \\
\hline $\mathbf{7 b}$ & -9.0632 \\
\hline $\mathbf{2}$ & -8.4895 \\
\hline
\end{tabular}




\section{Materials and Methods}

\subsection{General}

All the melting points were uncorrected. The infrared (IR) spectra $(\mathrm{KBr})$ were recorded on a Fourier-transform IR (FTIR) 5300 spectrometer (Nicolet ${ }^{\text {TM }}$ iS ${ }^{\mathrm{TM}}$ 10, Madison, WI, USA) $\left(v, \mathrm{~cm}^{-1}\right)$. The one-dimensional (1D) nuclear magnetic resonance (NMR) (1D NMR): ${ }^{1} \mathrm{H}$ NMR, ${ }^{13} \mathrm{C}$ NMR, the distortionless enhancement by polarization transfer (DEPT) 135, and the nuclear Overhauser effect (NOE) ${ }^{13} \mathrm{C}$ NMR and the two-dimensional (2D) (2D NMR): the homonuclear correlation spectroscopy (HH COSY) and heteronuclear COSY (CH COSY) spectra were recorded in DMSO- $d_{6}$ and $\mathrm{CDCl}_{3}$ at 400 and $500 \mathrm{MHz}$ on a JEOL (JEOL, Tokyo, Japan) and a Brucker (Avance 1ll, Zürich, Swetzerland) NMR spectrometer $(\delta, \mathrm{ppm})$ employing tetramethylsilane (TMS) as an internal standard, respectively. The mass spectra were obtained on a JEOL JMS600 H Root mass spectrometer (JEOL, Tokyo, Japan) at $70 \mathrm{eV}$. The elemental analysis was conducted by the Microanalytical Research Center, Faculty of Science, Cairo University, and the Microanalytical Research Center, Assiut University Broker Company, Switzerland Center. The spectral data are shown in Figures S16-S51 (supplemental information).

\subsection{Syntheses}

3.2.1. 6-Hydroxy-2-imino-4-methyl-1-(thiazol-2-yl)-1,2-dihydro-pyridine-3-carbonitrile (2)

A mixture of 3-oxobutanamide (1) $(1.84 \mathrm{~g}, 10 \mathrm{mmol})$ and an appropriate active methylene reagent (malononitrile) $(0.66 \mathrm{~g}, 10 \mathrm{mmol})$ in ethanol $(30 \mathrm{~mL})$ was treated with a few drops of piperidine and refluxed for $12 \mathrm{~h}$, after which it was left to cool. The resultant solid product was filtered out and recrystallized from ethanol to obtain $2(78 \%)$ as pale-yellow crystals. m.p. $=210{ }^{\circ} \mathrm{C}$; IR (KBr): $v=3312(\mathrm{O}-\mathrm{H}), 3058(\mathrm{ArC}-\mathrm{H}), 2921(\mathrm{AliC}-\mathrm{H}), 2215$ $(\mathrm{C} \equiv \mathrm{N}), 1673(\mathrm{C}=\mathrm{O}) \mathrm{cm}^{-1} ;{ }^{1} \mathrm{H} \mathrm{NMR}\left(\mathrm{CDCl}_{3}\right) \delta: 1.64(\mathrm{~s}, 1 \mathrm{H}, \mathrm{NH}), 2.31\left(\mathrm{~s}, 3 \mathrm{H}, \mathrm{CH}_{3}\right), 5.91(\mathrm{~s}$, $1 \mathrm{H}, \mathrm{CH}$-pyridine), 7.35 (d, 1H, CH-thiazole, $J=3.2 \mathrm{~Hz}), 7.70(\mathrm{~d}, 1 \mathrm{H}, \mathrm{CH}$-thiazole, $J=4 \mathrm{~Hz}$ ), 8.76 (br, $1 \mathrm{H}, \mathrm{OH}) \mathrm{ppm} ;{ }^{13} \mathrm{C}$ NMR $\delta: 20.91,104.60,116.79,119.26,135.67,152.22,155.30$, 157.06, 159.61 ppm; DEPT 135 NMR $\delta: ~(+) 20.87$ (q), 104.54 (d), 119.21 (d), 135.61 (d); MS (relative intensity) $m / z: 233.15$ (M+, 26\%). Anal. Calcd. for $\mathrm{C}_{10} \mathrm{H}_{8} \mathrm{~N}_{4} \mathrm{OS}$ (232.26): C, 51.71; $\mathrm{H}, 3.47$; N, 24.12; S, 13.81\%. Found: C, 51.69; H, 3.46; N, 24.14; S, 13.82\%.

\subsubsection{4-Methyl-6-(thiazol-2-ylamino)-2-thioxo-1,2-dihydropyridine-3-carbonitrile (3)}

A mixture of $1(1.84 \mathrm{~g}, 10 \mathrm{mmol})$ and cyanothioacetamide $(1 \mathrm{~g}, 10 \mathrm{mmol})$ in ethanol $(30 \mathrm{~mL})$ was treated with a few drops of piperidine and refluxed for $6 \mathrm{~h}$, after which it was left to cool before it was poured into crushed ice and acidified with $\mathrm{HCl}$. The solid product was collected and recrystallized from ethanol to yield $\mathbf{3}(67 \%)$ as dark-red crystals. m.p. $=170{ }^{\circ} \mathrm{C} ; \mathrm{IR}(\mathrm{KBr}): v=2247.63(\mathrm{C} \equiv \mathrm{N}) \mathrm{cm}^{-1} ;{ }^{1} \mathrm{H} \mathrm{NMR}\left(\mathrm{CDCl}_{3}\right) \delta: 2.55\left(\mathrm{~s}, 3 \mathrm{H}, \mathrm{CH}_{3}\right)$, $5.96(\mathrm{~s}, 1 \mathrm{H}, \mathrm{CH}$ Pyridine); $7.55(\mathrm{~d}, 1 \mathrm{H}, \mathrm{CH}$ thiazole, $J=4 \mathrm{~Hz}) ; 7.70(\mathrm{~d}, 1 \mathrm{H}, \mathrm{CH}$ thiazole, $J=4 \mathrm{~Hz}) ; 8.70(\mathrm{~s}, 1 \mathrm{H}, \mathrm{NH}), 12.58(\mathrm{~s}, 1 \mathrm{H}, \mathrm{NH}) \mathrm{ppm} ;{ }^{13} \mathrm{C}$ NMR $\delta: 12.26,75.05,104.62,116.54$, 119.17, 135.69, 152.42, 155.29, 157.34, 159.67 ppm; DEPT $135^{13}$ C NMR $\delta:(+) 12.34,104.52$, 119.41, 135.80. Anal. Calcd. for $\mathrm{C}_{10} \mathrm{H}_{8} \mathrm{~N}_{4} \mathrm{~S}_{2}$ (248.33): C, 48.37; H, 3.25; N, 22.56; S, 25.82\%. Found: C, $48.34 ; \mathrm{H}, 3.27 ; \mathrm{N}, 22.58 ; \mathrm{S}, 25.86 \%$.

\subsubsection{3-Acetyl-6-imino-1-(thiazol-2-yl)piperidin-2-one (5)}

A mixture of $1(1.84 \mathrm{~g}, 10 \mathrm{mmol})$ and acrylonitrile $(0.53 \mathrm{~g}, 10 \mathrm{mmol})$ in pyridine $(30 \mathrm{~mL})$ was heated under reflux for $6 \mathrm{~h}$, after which the reaction mixture was allowed to cool before it was poured onto crushed ice and acidified with a few drops of $\mathrm{HCl}$. The obtained solid product was filtered off and recrystallized from the aqueous ethanol to yield $5(63 \%)$ as yellow crystals. m.p. $=170{ }^{\circ} \mathrm{C} ;{ }^{1} \mathrm{H}$ NMR $\left(\mathrm{CDCl}_{3}\right)$ 8: $2.12\left(\mathrm{~s}, 3 \mathrm{H}, \mathrm{CH}_{3}\right), 2.17-2.39$ ( $\mathrm{m}, 2 \mathrm{H}, \mathrm{CH}_{2}$-pyridine), $2.84\left(\mathrm{t}, 2 \mathrm{H}, \mathrm{CH}_{2}\right.$-pyridine, $\left.\mathrm{J}=6.4 \mathrm{~Hz}\right), 4.35(\mathrm{t}, 1 \mathrm{H}, \mathrm{CH}$-pyridine, $J=6.4 \mathrm{~Hz}), 6.80(\mathrm{~d}, 1 \mathrm{H}, \mathrm{CH}$-thiazole, $J=4 \mathrm{~Hz}), 7.17(\mathrm{~d}, 1 \mathrm{H}, \mathrm{CH}$-thiazole, $J=5.2 \mathrm{~Hz}), 9.69(\mathrm{~s}$, $1 \mathrm{H}, \mathrm{NH}) \mathrm{ppm} ;{ }^{13} \mathrm{C}$ NMR $\delta: 12.68,26.95,27.44,63.44,110.48,119.21,126.25,167.66,177.58$, 205.05, ppm; DEPT $135{ }^{13}$ C NMR $8:(+) 12.76,(-) 27.03,(-) 27.51,(+) 63.44,110.57,126.35$; 
MS (relative intensity) $m / z: 238(\mathrm{M}+1,3.7 \%)$. Anal. Calcd. for $\mathrm{C}_{10} \mathrm{H}_{11} \mathrm{~N}_{3} \mathrm{O}_{2} \mathrm{~S}$ (237.28): $\mathrm{C}$, 50.62; H, 4.67; N, 17.71; S, 13.51\%. Found: C, 50.66; H, 4.63; N, 17.96; S, $13.52 \%$.

\subsubsection{Typical Procedure for Preparing 6a-c}

The aromatic amine $(10 \mathrm{mmol})$ was dissolved in a mixture of $\mathrm{HCl}(29 \mathrm{mmol})$ and $12 \mathrm{~mL}$ of water. The solution was cooled to $0^{\circ} \mathrm{C}$ in an ice bath, after which a solution of 11 mmol sodium nitrite was added into $2.4 \mathrm{~mL}$ of water with stirring, followed by cooling at a rate so that the temperature of the solution did not exceed $5{ }^{\circ} \mathrm{C}$. Next, the solution was added only until slightly excess nitrous acid was obtained. The resulting solution (benzenediazonium chloride) must be stored in the ice bath and utilized fairly quickly. Thereafter, the resulting solution (aryldiazonium salt) was added into a cold solution of $1(10 \mathrm{mmol})$ in ethanol $(50 \mathrm{~mL})$ containing sodium hydroxide $(6 \mathrm{~g})$, and the mixture was stirred for $1 \mathrm{~h}$ at $0{ }^{\circ} \mathrm{C}$. The solid product was formed, filtered off, washed severally with water, and recrystallized from the solvent to afford $\mathbf{6 a - c}$.

\subsubsection{3-Oxo-2-(2-phenylhydrazono)- $N$-(thiazol-2-yl)butanamide (6a)}

Compound 6a was obtained as yellow crystals from aqueous ethanol. Yield, 85\%; m.p. $=210{ }^{\circ} \mathrm{C} ;{ }^{1} \mathrm{H} \mathrm{NMR}\left(\mathrm{CDCl}_{3}\right) \delta: 2.57\left(\mathrm{~s}, 3 \mathrm{H}, \mathrm{CH}_{3}\right), 7.01\left(\mathrm{~d},{ }^{1} \mathrm{H}, \mathrm{CH}\right.$-thiazole, $\left.J=3.2 \mathrm{~Hz}\right)$, 7.19-7.23 (m, 5H, ArH), $7.53(\mathrm{~d}, 1 \mathrm{H}, \mathrm{CH}$-thiazole, $J=3.6 \mathrm{~Hz}), 12.63(\mathrm{~s}, 1 \mathrm{H}, \mathrm{NH}), 14.33(\mathrm{~s}, 1 \mathrm{H}$, $\mathrm{NH}) \mathrm{ppm} ;{ }^{13} \mathrm{C}$ NMR $\delta: 25.88,114.12,116.21,124.50,126.03,129.70,138.52,141.30,156.23$, 161.51, 198.84 ppm; DEPT $135{ }^{13} \mathrm{C}$ NMR $\delta:(+) 25.86,114.09,116.18,126.02,129.64,138.49$. Anal. Calcd. for $\mathrm{C}_{13} \mathrm{H}_{12} \mathrm{~N}_{4} \mathrm{O}_{2} \mathrm{~S}$ (288.32): C, 54.15; H, 4.20; N, 19.43; S, 11.12\%. Found: $\mathrm{C}$, $54.17 ; \mathrm{H}, 4.19 ; \mathrm{N}, 19.45 ; \mathrm{S}, 11.13 \%$.

\subsubsection{2-[2-(4-Methoxyphenyl)hydrazono]-3-oxo-N-(thiazol-2-yl)-butanamide(6b)}

Compound $\mathbf{6 b}$ was obtained as yellow crystals from aqueous ethanol. Yield, $87 \%$; m.p. $=318^{\circ} \mathrm{C} ; \mathrm{IR}(\mathrm{KBr}): v=3426,3120(2 \mathrm{~N}-\mathrm{H}) ; 3018(\mathrm{ArC}-\mathrm{H}) ; 2959(\mathrm{Al} \mathrm{C}-\mathrm{H}) ; 1647,1621$ $(2 \mathrm{C}=\mathrm{O}) \mathrm{cm}^{-1} ;{ }^{1} \mathrm{H}$ NMR $\left(\mathrm{CDCl}_{3}\right) \delta: 2.54\left(\mathrm{~s}, 3 \mathrm{H}, \mathrm{CH}_{3}\right), 3.81\left(\mathrm{~s}, 3 \mathrm{H}, \mathrm{OCH}_{3}\right), 6.92(\mathrm{~d}, 2 \mathrm{H}, \mathrm{ArH}$, $J=2 \mathrm{~Hz}), 6.94(\mathrm{~d}, 1 \mathrm{H}, \mathrm{ArH}, J=2 \mathrm{~Hz}), 6.99(\mathrm{~d}, 2 \mathrm{H}, \mathrm{CH}$-thiazole, $J=4 \mathrm{~Hz}), 7.36(\mathrm{~d}, 1 \mathrm{H}, \mathrm{ArH}$, $J=2.8 \mathrm{~Hz}), 7.38(\mathrm{~d}, 1 \mathrm{H}, \mathrm{ArH}, J=2.8 \mathrm{~Hz}), 7.52(\mathrm{~d}, 1 \mathrm{H}, \mathrm{CH}$-thiazole, $J=3.2 \mathrm{~Hz}), 12.67(\mathrm{~s}, 1 \mathrm{H}$, $\mathrm{NH}), 14.42(\mathrm{~s}, 1 \mathrm{H}, \mathrm{NH}) \mathrm{ppm} ;{ }^{13} \mathrm{C}$ NMR $\delta: 25.78,55.59,13.92,114.94,117.56,123.73,134.97$, 138.47, 156.34, 158.10, 161.74, 198.53 ppm; DEPT $135{ }^{13} \mathrm{C}$ NMR $\delta:(+) 25.75,55.59,113.92$, 114.93, 117.54, 138.46. Anal. Calcd. for $\mathrm{C}_{14} \mathrm{H}_{14} \mathrm{~N}_{4} \mathrm{O}_{3} \mathrm{~S}$ (318.35): C, 52.82; H, 4.43; N, 17.60; S, $10.07 \%$. Found: C, 52.84; H, 4.44; N, 17.61; S, $10.09 \%$.

\subsubsection{2-(2-(4-Chlorophenyl)hydrazono)-3-oxo- $N$-(thiazol-2-yl)-butanamide (6c)}

Compound $6 \mathrm{c}$ was obtained as yellow crystals from an aqueous ethanol. Yield, $89 \%$; m.p. $=180^{\circ} \mathrm{C}$; IR (KBr): $v=3418(\mathrm{~N}-\mathrm{H}), 3016(\mathrm{ArC}-\mathrm{H}), 2923(\mathrm{Al} \mathrm{C}-\mathrm{H}), 1653(2 \mathrm{C}=\mathrm{O}) \mathrm{cm}^{-1}$; ${ }^{1} \mathrm{H}$ NMR $\left(\mathrm{CDCl}_{3}\right) \delta: 2.55\left(\mathrm{~s}, 3 \mathrm{H}, \mathrm{CH}_{3}\right), 7.00(\mathrm{~d}, 1 \mathrm{H}, \mathrm{CH}$-thiazole, $J=4 \mathrm{~Hz}), 7.33-7.38(\mathrm{~m}, 4 \mathrm{H}$, ArH), $7.52(\mathrm{~d}, 1 \mathrm{H}, \mathrm{CH}$-thiazol, $J=3.6 \mathrm{~Hz}), 12.58(\mathrm{~s}, 1 \mathrm{H}, \mathrm{NH}), 14.33(\mathrm{~s}, 1 \mathrm{H}, \mathrm{NH}) \mathrm{ppm} ;{ }^{13} \mathrm{C}$ NMR $\delta: ~ 25.88,114.24,117.26,124.83,129.80,131.17,138.57,139.90,156.05,161.36,198.71$ ppm; DEPT $135{ }^{13} \mathrm{C}$ NMR $\delta:(+) 25.86,114.22,117.25,129.79,138.56$. Anal. Calcd. for $\mathrm{C}_{13} \mathrm{H}_{11} \mathrm{ClN}_{4} \mathrm{O} 2 \mathrm{~S}$ (322.77): C, 48.37; H, 3.44; N, 17.36; Cl, 10.98; S, 9.93\%. Found: C, 48.37; H, $3.44 ; \mathrm{N}, 17.36 ; \mathrm{Cl}, 10.99 ; \mathrm{S}, 9.91 \%$.

\subsubsection{Typical Procedure for Preparing 7a, $\mathbf{b}$}

A few drops of piperidine $(0.5 \mathrm{~mL})$ and appropriate aromatic aldehyde $(10 \mathrm{mmol})$ were added to a solution of $\mathbf{1}(1.84 \mathrm{~g}, 10 \mathrm{mmol})$ in ethanol $(30 \mathrm{~mL})$. The reaction mixture was heated under reflux for $6 \mathrm{~h}$, and the formed product was collected by filtration, after which it was recrystallized from the proper solvent to yield $\mathbf{7 a}, \mathbf{b}$.

\subsubsection{2-Benzylidene-3-oxo- $N$-(thiazol-2-yl)butanamide (7a)}

Compound $7 \mathbf{a}$ was obtained from 1 and benzaldehyde as yellow crystals from benzene. Yield, 82\%; m.p. $=197{ }^{\circ} \mathrm{C} ;{ }^{1} \mathrm{H}$ NMR $\left(\mathrm{DMSO}_{6}\right) \delta: 2.11\left(\mathrm{~s}, 3 \mathrm{H}, \mathrm{CH}_{3}\right), 7.01(\mathrm{~d}, 1 \mathrm{H}, \mathrm{CH}-$ 
thiazole, $J=7.2 \mathrm{~Hz}), 7.34-7.56(\mathrm{~m}, 1 \mathrm{H}, \mathrm{Ar}-\mathrm{H}), 7.60-7.63(\mathrm{~m}, 4 \mathrm{H}-\mathrm{Ar}-\mathrm{H}), 7.80(\mathrm{~d}, 1 \mathrm{H}, \mathrm{CH}-$ thiazole, $J=7.6 \mathrm{~Hz}), 9.04$ (s, 1H, CH-aliphatic), 12.46 (s, 1H, NH) ppm; ${ }^{13} \mathrm{C}$ NMR $\delta: 25.77$, 109.66, 114.12, 116.21, 124.49, 126.03, 129.70, 138.52, 141.30, 156.17, 161.51, 198.86 ppm; DEPT $135{ }^{13}$ C NMR $\delta:(+) 25.76,109.66,114.13,116.18,126.02,129.70,138.56$. Anal. Calcd. for $\mathrm{C}_{14} \mathrm{H}_{12} \mathrm{~N}_{2} \mathrm{O}_{2} \mathrm{~S}$ (272.32): C, 61.75; $\mathrm{H}, 4.41 ; \mathrm{N}, 10.29 ; \mathrm{S}, 11.77 \%$. Found: $\mathrm{C}, 61.73 ; \mathrm{H}, 4.46$; $\mathrm{N}, 10.27 ; \mathrm{S}, 11.80 \%$.

\subsubsection{2-(4-Methoxybenzylidene)-3-oxo-N-(thiazol-2-yl)butanamide (7b)}

Compound $\mathbf{7 b}$ was obtained from $\mathbf{1}$ and p-methoxy-benzaldehyde as brown crystals from benzene. Yield, 56\%; m.p. $=190{ }^{\circ} \mathrm{C} ;{ }^{1} \mathrm{H}$ NMR $\left(\mathrm{DMSO}_{-} d_{6}\right) \delta: 2.40\left(\mathrm{~s}, 3 \mathrm{H}, \mathrm{CH}_{3}\right), 3.72(\mathrm{~s}$, $\left.3 \mathrm{H}, \mathrm{OCH}_{3}\right), 6.96(\mathrm{~d}, 2 \mathrm{H}, \mathrm{ArH}, J=8.8 \mathrm{~Hz}), 7.28(\mathrm{~d}, 1 \mathrm{H}, \mathrm{CH}$-thiazole, $J=2.8 \mathrm{~Hz}), 7.46-7.50$ (m, 3H, 1H-CH thiazole, 2H-ArH), 7.73 (s,1H, Ali-CH), 12.51 (s, 1H, NH) ppm; ${ }^{13} \mathrm{C}$ NMR $\delta: 26.01,55.48,113.96,114.68,125.34,131.19,133.85,137.96,141.43,157.64,161.46,166.05$, 196.28 ppm; DEPT $135{ }^{13} \mathrm{C}$ NMR $\delta:(+) 25.93,55.39,113.89,114.60,131.84,137.88,141.36$. Anal. Calcd. for $\mathrm{C}_{15} \mathrm{H}_{14} \mathrm{~N}_{2} \mathrm{O}_{3} \mathrm{~S}$ (302.35): C, 59.59; $\mathrm{H}, 4.67 ; \mathrm{N}, 9.27 ; \mathrm{S}, 10.61 \%$. Found: C, 59.58; H, 4.65; N, 9.28; S, $10.62 \%$.

\subsubsection{Typical Procedure for Preparing $\mathbf{8 a , b}$}

A few drops of $\mathrm{HCl}(0.5 \mathrm{~mL})$, thiourea $(0.76 \mathrm{~g}, 10 \mathrm{mmol})$, and aromatic aldehyde (10 mmol) were added to a solution of $\mathbf{1}(1.84 \mathrm{~g}, 10 \mathrm{mmol})$ in ethanol $(30 \mathrm{~mL})$ and heated under reflux for $6 \mathrm{~h}$. Thereafter, the solid product, which was produced while it was hot, was collected by filtration and recrystallized from the proper solvent to afford $\mathbf{8 a}, \mathbf{b}$.

4-(4-Fluorophenyl)-6-methyl-N-(thiazol-2-yl)-2-thioxo-1,2,3,4-tetra-hydropyrimidine -5-carboxamide (8a)

Compound 8a was obtained from 1, p-florobenzaldehyde, and thiourea as white crystals from aqueous ethanol. Yield, $67 \%$; m.p. $=187^{\circ} \mathrm{C}$; IR $(\mathrm{KBr}): v=3407(\mathrm{NH}) ; 3002$

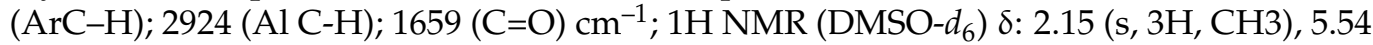
(s, 1H, 4H-pyrimidine), 7.14-7.43 (m, 6H, 2CH-thiazole, 4-ArH), 9.60 (s, 1H, NH), 10.20 (s, 1H, NH), 11.96 (s, 1H, NH) ppm; ${ }^{13} \mathrm{C}$ NMR $\delta: 16.88,53.73,104.10,113.46,115.45,115.67$, 128.71, 128.80, 139.06, 139.66, 160.50, 162.94, 173.88 ppm; DEPT $135^{13}$ C NMR $\delta:(+) 16.78$, 53.63, 115.37, 115.57, 128.62, 128.70. Anal. Calcd. for $\mathrm{C}_{15} \mathrm{H}_{13} \mathrm{FN}_{4} \mathrm{OS}_{2}$ (348.42): $\mathrm{C}, 51.71 ; \mathrm{H}$, 3.76; N, 16.08; F, 5.45; S, 18.41\%. Found: C, 51.70; H, 3.78; N, 16.06; F, 5.44; S, $18.43 \%$.

4-(4-Methoxyphenyl)-6-methyl-N-(thiazol-2-yl)-2-thioxo-1,2,3,4-tetrahydropyrimidine -5-carboxamide $(\mathbf{8 b})$

Compound $\mathbf{8 b}$ was obtained from $\mathbf{1}, \mathrm{p}$-methoxybenzaldehyde, and thiourea as orange crystals from aqueous ethanol. Yield, 59\%; m.p. $=290{ }^{\circ} \mathrm{C}$; IR (KBr): $v=3435(\mathrm{NH}) ; 3015$ $(\mathrm{ArC}-\mathrm{H}) ; 2999$ (Ali-C-H); $1661(\mathrm{C}=\mathrm{O}) \mathrm{cm}^{-1} ;{ }^{1} \mathrm{H}$ NMR (DMSO-d $)$ ) $: 2.14$ (s, 3H, $\left.\mathrm{CH}_{3}\right) ; 3.68$ $\left(\mathrm{s}, 3 \mathrm{H}, \mathrm{OCH}_{3}\right) ; 5.50$ (s, 1H, 4H-pyrimidine); 6.87-7.43(m, 6H, 2CH-thiazole, 4ArH); 9.53 (s, $1 \mathrm{H}, \mathrm{NH}) ; 10.13$ (s, 1H, NH); 11.92 (s, 1H, NH) ppm; ${ }^{13} \mathrm{C}$ NMR $\delta: 16.83,53.88,55.16,104.03$, 114.01, 114.07, 127.93, 127.99, 131.84, 135.00, 137.44, 139.28, 158.96, 164.63, 173.63 ppm; DEPT $135{ }^{13} \mathrm{C}$ NMR $\delta:(+) 17.22,54.72,55.69,114.22,114.68,128.37,128.73$; MS (relative intensity) $m / z: 362.12\left(\mathrm{M}+2,0.9 \%\right.$ ). Anal. Calcd. for $\mathrm{C}_{16} \mathrm{H}_{16} \mathrm{~N}_{4} \mathrm{O}_{2} \mathrm{~S}_{2}$ (360.45): $\mathrm{C}, 53.31 ; \mathrm{H}$, 4.47; N, 15.54; S, 17.79\%. Found: C, 53.30; H, 4.45; N, 15.56; S, 17.77\%.

3.2.12. 4,4'-(1,4-.Phenylene)bis(6-methyl-N-(thiazol-2-yl)-2-thioxo-1,2,3,4tetrahydropyrimidine-5-carboxamide) (9)

$\mathrm{HCl}(2 \mathrm{~mL})$, terphthaldehyde $(0.68 \mathrm{~g}, 5 \mathrm{mmol})$ and thiourea $(0.76 \mathrm{~g}, 10 \mathrm{mmol})$ were added to a solution of $\mathbf{1}(1.84 \mathrm{~g}, 10 \mathrm{mmol})$ in ethanol $(30 \mathrm{~mL})$. The reaction mixture was heated under reflux for $12 \mathrm{~h}$, after which the solid product, which was formed while it was hot, was collected by filtration and recrystallized from dioxane/ethanol to afford $9(68 \%)$ as yellow crystals; m.p. $=>300{ }^{\circ} \mathrm{C} ;{ }^{1} \mathrm{H}$ NMR $\left(\right.$ DMSO- $\left._{6}\right) \delta: 2.10\left(\mathrm{~s}, 6 \mathrm{H}, 2 \mathrm{CH}_{3}\right), 5.45(\mathrm{~s}, 1 \mathrm{H}$, CH-pyrimidine), 5.47 (s, 1H, CH-pyrimidine), 7.13-7.26 (m, 2H, CH-thiazole), 7.25-7.42 
(m, 4H, Ar-H), 7.46-7.48 (m, 2H, CH-thiazole), 9.49 (s, 1H, NH), 9.54 (s, 1H, NH), 10.14 $(\mathrm{s}, 2 \mathrm{H}, 2 \mathrm{NH}), 11.91$ (s, 2H, 2NH) ppm; ${ }^{1} \mathrm{H}$ NMR (DMSO-d $\left.6+\mathrm{D}_{2} \mathrm{O}\right) \delta: 2.09\left(\mathrm{~s}, 6 \mathrm{H}, 2 \mathrm{CH}_{3}\right)$, 5.41 (s, 1H, CH-pyrimidine), 5.43(s, 1H, CH-pyrimidine), 7.09-7.45 (m, 8H, 4CH-thiazole, $4 \mathrm{Ar}-\mathrm{H}) \mathrm{ppm} ;{ }^{13} \mathrm{C}$ NMR $\delta: 16.83,54.01,104.17,113.54,126.81,135.76,139.10,142.54,158.14$, 164.50, 174.01 ppm; DEPT $135{ }^{13} \mathrm{C}$ NMR $\delta:(+) 16.73,54.16,113.43,126.72,137.60$. Anal. Calcd. for $\mathrm{C}_{24} \mathrm{H}_{22} \mathrm{~N}_{8} \mathrm{O}_{2} \mathrm{~S}_{4}$ (582.74): C, 49.47; H, 3.81; N, 19.23; S, 22.01\%. Found: C, 49.42; H, $3.84 ; \mathrm{N}, 19.18 ; \mathrm{S}, 22.05 \%$.

\subsubsection{Typical Procedure for Preparing 10a,b}

A mixture of $\mathbf{1}(10 \mathrm{mmol})$, an appropriate active methylene reagent, malononitrile or ethylcyanoacetate $(10 \mathrm{mmol})$, and sulfur in ethanol $(20 \mathrm{~mL})$ in the presence of a catalytic amount of morpholine was heated under reflux for $5 \mathrm{~h}$ at $55-70{ }^{\circ} \mathrm{C}$, after which it was allowed to cool. The obtained solid product was filtered off and recrystallized from the proper solvent to afford $\mathbf{1 0 a}, \mathbf{b}$.

5-Amino-4-cyano-2-methyl-N-(thiazol-2-yl)thiophene-3-carboxamide (10a)

Compound 10a was obtained from 1 and malononitrile as dark brown crystals from the aqueous ethanol. Yield, 73\%; m.p. $=215^{\circ} \mathrm{C}$; IR $(\mathrm{KBr}): v=2246.75(\mathrm{C} \equiv \mathrm{N}) \mathrm{cm}^{-1} ;{ }^{1} \mathrm{H}$ NMR (DMSO-d 6 ) $\delta: 2.17\left(\mathrm{~s}, 3 \mathrm{H}, \mathrm{CH}_{3}\right), 4.21$ (s, 2H, NH , exchangeable), 7.85 (d, 1H, CHthiazole, $J=4 \mathrm{~Hz}$ ), 7.90 (d, 1H, CH-thiazole, $J=3.6 \mathrm{~Hz}), 9.69$ (s, 1H, NH, exchangeable) ppm; ${ }^{13}$ C NMR $\delta: 20.63,103.77,116.70,123.56,139.76,153.17,154.98,155.80,160.08,164.87$ ppm; DEPT $135{ }^{13} \mathrm{C}$ NMR $\delta:(+) 20.58,123.53,139.72$; MS (relative intensity) $\mathrm{m} / z: 264.93$ $(\mathrm{M}+, 12 \%)$. Anal. Calcd. for $\mathrm{C}_{10} \mathrm{H}_{8} \mathrm{~N}_{4} \mathrm{OS}_{2}$ (264.33): C, 45.44; H, 3.05; N, 21.20; S, $24.26 \%$. Found: C, 45.47; H, 3.04; N, 21.23; S, 24.25\%.

Ethyl 2-amino-5-methyl-4-(thiazol-2-ylcarbamoyl)thiophene-3-carboxylate (10b)

Compound $\mathbf{1 0 b}$ was obtained from 1 and ethylcyanacetate as brown crystals from the aqueous ethanol. Yield, 65\%; m.p. $=198{ }^{\circ} \mathrm{C}$; IR (KBr): $v=3358(\mathrm{NH}), 3021(\mathrm{ArC}-\mathrm{H})$, 2981 (Ali-C-H), $1706(\mathrm{C}=\mathrm{O}) \mathrm{cm}^{-1},{ }^{1} \mathrm{H}$ NMR $\left(\mathrm{DMSO}_{6}\right) \delta: 1.24\left(\mathrm{t}, 3 \mathrm{H}, \mathrm{CH}_{3}, J=6.8 \mathrm{~Hz}\right)$, $2.60\left(\mathrm{~s}, 3 \mathrm{H}, \mathrm{CH}_{3}\right), 4.21\left(\mathrm{q}, 2 \mathrm{H}, \mathrm{CH}_{2}, J=6.8 \mathrm{~Hz}\right), 7.05(\mathrm{~d}, 1 \mathrm{H}, \mathrm{CH}$-thiazole, $J=4 \mathrm{~Hz}), 7.40(\mathrm{~d}$, $1 \mathrm{H}, \mathrm{CH}$-thiazole, $J=4 \mathrm{~Hz}), 7.82\left(\mathrm{~s}, 2 \mathrm{H}, \mathrm{NH}_{2}\right), 12.16(\mathrm{~s}, 1 \mathrm{H}, \mathrm{NH}) \mathrm{ppm} ;{ }^{13} \mathrm{C}$ NMR $\delta: 14.34$, $16.33,59.41,106.25,112.01,112.03,132.14,143.69,162.02,164.03,165.00,166.07$ ppm; DEPT $135{ }^{13}$ C NMR $\delta:(+) 14.35,16.36,(-) 59.42,(+) 112.01,132.14 ;$ NOE NMR $\delta: 12.47-18.29$ (m, $\left.2 \mathrm{CH}_{3}\right), 57.98\left(\mathrm{t}, \mathrm{CH}_{2}\right), 106.27(\mathrm{~s}), 111.01$ (d, 1H, CH-thiazole), 113.03 (s), $132.99(\mathrm{~d}, 1 \mathrm{H}$, CH-thiazole), 143.67 (s), 162.13 (s), 164.08 (s), 165.03 (s), 166.10 (s); MS (relative intensity) m/z: $312.08(\mathrm{M}+, 1.4 \%)$. Anal. Calcd. for $\mathrm{C}_{12} \mathrm{H}_{13} \mathrm{~N}_{3} \mathrm{O}_{3} \mathrm{~S}_{2}$ (311.38): C, 46.29; $\mathrm{H}, 4.21 ; \mathrm{N}, 13.49$; S, 20.60\%. Found: C, 46.30; H, 4.23; N, 13.47; S, 20.61\%.

\subsubsection{Typical Procedure for Preparing 11a-c}

A mixture of $\mathbf{6 a}-\mathbf{c}(10 \mathrm{mmol})$ and dimethylformamide-dimethylacetal (DMF-DMA) $(10 \mathrm{mmol})$ was heated under reflux for $5 \mathrm{~min}$ in dioxane. Thereafter, the solid that was formed upon cooling was collected and recrystallized from the proper solvents to afford $(11 \mathrm{a}-\mathrm{c})$.

4-Oxo-1-phenyl-N-(thiazol-2-yl)-1,4-dihydropyridazine-3-carboxamide (11a)

Compound 11a was obtained as brown crystals from aqueous ethanol. Yield, 65\%; m.p. $=230{ }^{\circ} \mathrm{C}$; IR $(\mathrm{KBr}): v=3429(\mathrm{~N}-\mathrm{H}), 3090(\mathrm{ArC}-\mathrm{H}), 1687(2 \mathrm{C}=\mathrm{O}) \mathrm{cm}^{-1} ;{ }^{1} \mathrm{H}$ NMR $\left(\mathrm{DMSO}-\mathrm{d}_{6}\right) \delta: 7.01$ (d, 1H, CH-pyridazine, $\left.J=7.2 \mathrm{~Hz}\right), 7.34(\mathrm{~d}, 1 \mathrm{H}, \mathrm{CH}$-thiazole, $J=1.6 \mathrm{~Hz}$ ), 7.50-7.63 (m, 4H, ArH), 7.80 (d, 2H, ArH, J = 7.6 Hz), 9.04 (d, 1H, CH-pyridazine, $J=7.6 \mathrm{~Hz}), 13.61(\mathrm{~s}, 1 \mathrm{H}, \mathrm{NH}) \mathrm{ppm} ;{ }^{13} \mathrm{C}$ NMR $\delta: 114.89,121.43,121.59,128.98,129.80$, 138.31, 142.24, 142.93, 144.46, 156.70, 158.96, 169.97 ppm; DEPT $135{ }^{13}$ C NMR $\delta:(+) 114.84$, 121.38, 121.54, 128.93, 129.75, 138.26, 142.19. Anal. Calcd. for $\mathrm{C}_{14} \mathrm{H}_{10} \mathrm{~N}_{4} \mathrm{O}_{2} \mathrm{~S}$ (298.32): C, 56.37; H, 3.38; N, 18.78; S, 10.75\%. Found: C, 56.35; H, 3.36; N, 18.79; S, $10.76 \%$. 
1-(4-Methoxyphenyl)-4-oxo-N-(thiazol-2-yl)-1,4-dihydro-pyridazine-3-carboxamide (11b)

Compound $\mathbf{1 1 b}$ was obtained as brown crystals from the aqueous ethanol. Yield, 65\%; m.p. $=237^{\circ} \mathrm{C}$; IR (KBr): $v=3420(\mathrm{NH}), 3089(\mathrm{ArC}-\mathrm{H}), 2931(\mathrm{Ali}-\mathrm{C}-\mathrm{H}), 1689(2 \mathrm{C}=\mathrm{O}) \mathrm{cm}^{-1}$; ${ }^{1} \mathrm{H}$ NMR (DMSO-d $\left.)_{6}\right) \delta: 3.82\left(\mathrm{~s}, 3 \mathrm{H}, \mathrm{OCH}_{3}\right), 7.00(\mathrm{~d}, 1 \mathrm{H}, \mathrm{CH}-$ pyridazine, $J=8 \mathrm{~Hz}), 7.13$ (d, 2H, ArH, J = 8.8 Hz), $7.34(\mathrm{~d}, 1 \mathrm{H}, \mathrm{CH}$-thiazole, $J=3.6 \mathrm{~Hz}), 7.55$ (d, 1H, CH-thiazole, $J=4 \mathrm{~Hz}), 7.70(\mathrm{~d}, 2 \mathrm{H}, \mathrm{ArH}, J=8.8 \mathrm{~Hz}), 8.96(\mathrm{~d}, 1 \mathrm{H}, \mathrm{CH}$-pyridazine, $J=7.6 \mathrm{~Hz}), 13.70(\mathrm{~s}, 1 \mathrm{H}$, NH) ppm; ${ }^{13}$ C NMR $\delta: 55.69,114.73,114.84,121.54,123.17,136.42,138.29,142.34,143.97$, 156.70, 158.94, 159.52, 169.80 ppm; DEPT $135{ }^{13} \mathrm{C}$ NMR $\delta:(+) 55.69,114.70,114.83,121.51$, 123.15, 138.27, 142.34. Anal. Calcd. for $\mathrm{C}_{15} \mathrm{H}_{12} \mathrm{~N}_{4} \mathrm{O}_{3} \mathrm{~S}$ (328.35): C, 54.87; H, 3.68; N, 17.06; S, 9.77\%. Found: C, 54.88; H, 3.66; N, 17.08; S, 9.75\%.

1-(4-Chlorophenyl)-4-oxo- $N$-(thiazol-2-yl)-1,4-dihydro-pyridazine-3-carboxamide (11c)

Compound 11c was obtained as brown crystals from the aqueous ethanol. Yield, $67 \%$; m.p. $=295{ }^{\circ} \mathrm{C}$; IR $(\mathrm{KBr}): v=3431(\mathrm{NH}), 3099(\mathrm{ArC}-\mathrm{H}), 1688(2 \mathrm{C}=\mathrm{O}) \mathrm{cm}^{-1} ;{ }^{1} \mathrm{H}$ NMR (DMSO- $\left.d_{6}\right) \delta: 7.012(\mathrm{~d}, 1 \mathrm{H}, \mathrm{CH}$-pyridazine, $J=7.6 \mathrm{~Hz}), 7.35$ (d, 1H, CH-thiazole, $J=3.2 \mathrm{~Hz}), 7.56(\mathrm{~d}, 1 \mathrm{H}, \mathrm{CH}$-thiazole, $J=2.8 \mathrm{~Hz}), 7.68(\mathrm{~d}, 2 \mathrm{H}, \mathrm{ArH}, J=8.4 \mathrm{~Hz}), 7.84(\mathrm{~d}, 2 \mathrm{H}$, $\mathrm{ArH}, J=8.4 \mathrm{~Hz}), 9.03$ (d, 1H, CH-pyridazine, $J=8 \mathrm{~Hz}), 13.53(\mathrm{~s}, 1 \mathrm{H}, \mathrm{NH}) \mathrm{ppm} ;{ }^{13} \mathrm{C}$ NMR $\delta$ : 114.91, 121.28, 123.28, 129.70, 133.37, 138.31, 141.66, 142.08, 144.64, 156.70, 158.89, 169.92 ppm; DEPT $135{ }^{13}$ C NMR $\delta:(+) 114.88,121.23,123.27,129.67,138.26,142.06$. Anal. Calcd. for $\mathrm{C}_{14} \mathrm{H}_{9} \mathrm{ClN}_{4} \mathrm{O}_{2} \mathrm{~S}$ (332.76): C, 50.53; H, 2.73; N, 16.84; Cl, 10.65; S, 9.64\%. Found: C, 50.56; $\mathrm{H}, 2.72 ; \mathrm{N}, 16.85 ; \mathrm{Cl}, 10.64 ; \mathrm{S}, 9.65 \%$.

\subsubsection{5. $\mathrm{N}$-(5-(4-Chlorophenyl)-5H-pyrazolo[4,3-c]pyridazin-3-yl)-thiazol-2-amine (12)}

A mixture of $11 \mathrm{c}(3.32 \mathrm{~g}, 10 \mathrm{mmol})$ and hydrazine hydrate $(0.6 \mathrm{~g}, 15 \mathrm{mmol})$ was fused for $5 \mathrm{~min}$ in a round-bottomed flask. Thereafter, pyridine $(30 \mathrm{~mL})$ was added, and the mixture was heated under reflux for $12 \mathrm{~h}$. Afterward, it was allowed to cool. The obtained solid product was filtered off and recrystallized from the aqueous ethanol to afford 12 $(68 \%)$ as yellow crystals. m.p $=157^{\circ} \mathrm{C}$; IR $(\mathrm{KBr}): v=3267(\mathrm{~N}-\mathrm{H}) ; 3015(\mathrm{ArC}-\mathrm{H}) \mathrm{cm}^{-1}$; ${ }^{1} \mathrm{H}$ NMR (DMSO- $\left.d_{6}\right) \delta: 7.07(\mathrm{~d}, 1 \mathrm{H}, \mathrm{CH}$-thiazole, $J=1.2 \mathrm{~Hz}) 7.24(\mathrm{~d}, 1 \mathrm{H}, \mathrm{CH}$-pyridazine, $J=2.4 \mathrm{~Hz}), 7.37(\mathrm{~d}, 2 \mathrm{H}, \mathrm{ArH}, J=8.4 \mathrm{~Hz}), 7.52(\mathrm{~d}, 1 \mathrm{H}, \mathrm{CH}$-pyridazine, $J=2.8 \mathrm{~Hz}), 7.56(\mathrm{~d}$, $2 \mathrm{H}, \mathrm{ArH}, J=8.4 \mathrm{~Hz}), 7.96(\mathrm{~d}, 1 \mathrm{H}, \mathrm{CH}$-thiazole, $J=1.6 \mathrm{~Hz}), 13.04(\mathrm{~s}, 1 \mathrm{H}, \mathrm{NH}) \mathrm{ppm} ;{ }^{13} \mathrm{C}$ NMR $\delta: 106.49,109.86,113.69,116.44,125.26,125.92,129.24,137.86,142.08,144.72,158.30$, 162.99 ppm; DEPT $135{ }^{13}$ C NMR $\delta:(+) 106.30,109.66,113.53,116.26,129.06,137.68$; MS; $m / z=329.76(\mathrm{M}+1)$. Anal. Calcd. for $\mathrm{C}_{14} \mathrm{H}_{9} \mathrm{ClN}_{6} \mathrm{~S}$ (328.78): $\mathrm{C}, 51.14 ; \mathrm{H}, 2.76 ; \mathrm{N}, 25.56 ; \mathrm{Cl}$, 10.78; S, 9.75\%. Found: C, 51.16; H, 2.77; N, 25.54; Cl, 10.77; S, 9.76\%.

3.2.16. (Z)-N-(5-(4-Chlorophenyl)-2-phenyl-2H-pyrazolo[4,3-c]-pyridazin-3(5H)ylidene)thiazol-2-amine (13)

A mixture of 11c (3.32 $\mathrm{g}, 10 \mathrm{mmol})$ and phenylhydrazine $(1.08 \mathrm{~g}, 10 \mathrm{mmol})$ was fused for $5 \mathrm{~min}$, after which acetic acid $(30 \mathrm{~mL})$ containing $2 \mathrm{~g}$ of sodium acetate was added before the mixture was heated under reflux for $12 \mathrm{~h}$. Afterward, it was allowed to cool before it was poured into ice-cold water. The obtained solid product was filtered off and recrystallized from the aqueous ethanol to afford 13 (54\%) as pink crystals. m.p. $=320{ }^{\circ} \mathrm{C}$; IR (KBr): $v=3046(\mathrm{ArC}-\mathrm{H}) \mathrm{cm}^{-1} ;{ }^{1} \mathrm{H}$ NMR (DMSO-d $\left.6+\mathrm{CDCl}_{3}\right) \delta: 7.15-7.19(\mathrm{~m}, 1 \mathrm{H}, \mathrm{ArH})$, 7.37-7.42 (m, 3H; 1H-CH pyridazine, 2H-CH thiazole), 7.55 (d, 2H, ArH, J = 8.8 Hz), 7.79 (d, 2H, ArH, $J=8.8 \mathrm{~Hz}), 8.06-8.12(\mathrm{~m}, 4 \mathrm{H}, \mathrm{Ar}-\mathrm{H}), 8.52$ (d, 1H, CH-pyridazine, $J=8 \mathrm{~Hz}$ ) ppm; ${ }^{13}$ C NMR $\delta: 111.22,113.94,115.78,118.88,122.76,125.13,128.53,129.50,133.32,133.60$, 134.06, 138.95, 141.68, 141.83, 147.44, 157.25 ppm; DEPT $135{ }^{13}$ C NMR $\delta:(+) 111.26,113.99$, $118.91,122.79,125.19,128.57,129.54,133.62,147.46$; MS (relative intensity) $m / z: 405.88$ $(\mathrm{M}+1,9.1 \%)$. Anal. Calcd. for $\mathrm{C}_{20} \mathrm{H}_{13} \mathrm{ClN}_{6} \mathrm{~S}$ (404.88): C, 59.33; H, 3.24; N, 20.76; Cl, 8.76; $\mathrm{S}$, 7.92\%. Found: C, 59.31; H, 3.26; N, 20.74; Cl, 8.78; S, 7.93\%. 


\subsection{Pharmacological Assessment}

\subsubsection{PDE5 Enzyme Activity Assay Procedure}

The standard enzymatic reaction mixture (total volume, $200 \mu \mathrm{L}$ ) contained $100 \mathrm{~mL}$ of mTris- $\mathrm{HCl}$ buffer (pH 8.3), $10 \mathrm{mM} \mathrm{MgCl}_{2}$, and $10 \mathrm{mM} \mathrm{KCl}$ at $37^{\circ} \mathrm{C}$. Alfa-casein $(2 \mathrm{mg})$ was utilized as a carrier for the precipitation of protein at a low concentration (PDE-A1) of enzyme sample (final protein concentration, $0.5 \mathrm{mg} / \mathrm{mL}$ ). A concentration $(104 \mathrm{nM})$ of the agents under study (the sildenafil analogs) was prepared in DMSO and pre-incubated in the enzymatic mixture for $5 \mathrm{~min}$ at room temperature. The reaction was initiated by the addition of the substrate, cGMP $(5 \mu \mathrm{M})$ for $30 \mathrm{~min}$ at $35^{\circ} \mathrm{C}$. The reaction was terminated by the transfer of the reaction mixture tubes into a boiling water bath for $3 \mathrm{~min}$. Thereafter, the sample was centrifuged and filtered through a nylon- 66 filter $(0.2 \mathrm{~mm}$, Rainin Corporation). The clear filtrate obtained might be utilized directly for the highperformance liquid chromatography assay or stored at $-20^{\circ} \mathrm{C}$. A blank containing protein, which was denaturized in the boiling water bath for $3 \mathrm{~min}$, was performed with and without cGMP. Both the incubation time and enzyme concentration were adjusted to ensure that no more than $25 \%$ of the substrate was hydrolyzed under the assay conditions. The chromatographic system was G1315D DAD (Agilent Technologies 1200 Series, Santa Carla, California, USA). The utilized column was Zorbax Eclipse with rapid resolutions (4.69 $\mathrm{mm} \times 150 \mathrm{~mm}, 3.51 \mathrm{M}$ particle size). The mobile phase employed for the separation (isocratic elution) consisted of $200 \mathrm{mM}$ ammonium acetate ( $\mathrm{pH}$ 6.0) with $2 \%$ acetonitrile $(v / v)$. The flow rate was $1.5 \mathrm{~cm}^{3} \cdot \mathrm{min}^{-1}$ with diode-array detection (DAD) at $254 \mathrm{~nm}$, and the injection volume was $30 \mathrm{~mm}^{3}$. The peak identities were confirmed by the co-elution with the standards. All the assays were performed in duplicate $[20,27]$.

\subsubsection{ABP Measurement}

Regardless of the sex factor, white New Zealand rabbits weighing 2-2.5 kg were obtained from the animal house of the Faculty of Medicine, Assiut University. The animals were housed for one week to adapt to the environmental conditions. The rabbits were fed with a standard diet and allowed free access to water. The experiment was performed according to the accepted guidelines for animal care. Sixty-four normotensive white New Zealand rabbits $(2-2.5 \mathrm{~kg}$ ) of either sex were utilized for this assay (four rabbits in each group) to evaluate the possible vasorelaxant effects of the selected compounds. The external jugular vein was also tightly cannulated for the administration of the tested compound in a dose of $0.5 \mathrm{mg} / \mathrm{kg}$, followed by heparinized saline $(0.90 \%(w / v) \mathrm{NaCl})$. The effect on the MABP appeared within one minute. The normotensive rabbits were anesthetized with pentobarbital sodium $(30 \mathrm{mg} / \mathrm{kg}$, IV). Thereafter, they were laid on their backs with their legs fixed and their heads pinned. Next, their tracheas were exposed and cut before they were firmly cannulated. Following the separation, the two muscle bundles, the sternomastoid and the sternothyroid, which are the common carotid arteries in the neck between the lateral bundles of muscle (longus capitis) and the trachea, were exposed and carefully separated from the nerves, veins, and connective tissue. A heparinized cannula was carefully inserted and firmly bound with a fine thread. Thereafter, the cannula was connected to a pressure transducer utilizing a universal oscillograph (Harvard apparatus, ser. No. K10542) for recording the blood pressure. The external jugular vein was also tightly cannulated for the administration of the tested compounds, followed by heparinized saline $(0.90 \%(w / v) \mathrm{NaCl})[20]$.

$\mathrm{MABP}$ was calculated by the following formula: $\mathrm{MABP}=\mathrm{DBP}+1 / 3(\mathrm{SBP}-\mathrm{DBP})$, where DBP is the diastolic blood pressure, SBP is the systolic blood pressure.

The statistical analysis was conducted with the GraphPad Prism 5.0 software (Graph$\mathrm{Pad}$, San Diego, CA, USA). The data were represented as the mean \pm SE. Further, multiple comparisons were conducted by the one-way ANOVA employing the Tukey-Kramer test as the multiple comparison post-ANOVA test. $p<0.05$ was selected as the statistical significance. 


\subsection{Molecular Modeling}

\subsubsection{Lead Optimization by Scaffold Hopping}

The molecular shape and electrostatic similarity were determined by the OpenEye EON scientific software by replacing the whole molecules with the reference drug (sildenafil) to ensure the achievement of physically realistic electrostatic potential comparisons (OpenEye, 2020b). EON significantly contributes to lead generation and library design.

\subsubsection{Structure-Based Lead Discovery}

The designed and synthesized compounds were docked into PDE5 (PDB ID: 2H42) [29] by an OpenEye-applications-2020-Spring released software. To validate our study, the docking protocol commenced with sildenafil as the standard ligand that was co-crystallized with $2 \mathrm{H} 42$. The designed compounds were first subjected to a filtering process utilizing the OpenEye filter-4.0.0.4 application [33], which calculates MW, XlogP, XlogS, PSA, the hydrogen-bond donor and acceptor counts, rotatable bonds, ring size and number, etc. Moreover, the filtering process was assigned a graph-based protonation state for consistency and speed; it affords ADME filters, such as Lipinski, Egan, Veber, and Martin. The compounds with impossible bonding and inappropriate elements were removed. Thereafter, the library was processed through the OpenEye Omega2-4.0.0.4 application in which the 3D conformations of the molecules were generated with an extension of the OBinary file. Next, the OpenEye docking (OEDocking) was performed by the FRED application [31,33]. The FRED-3.5.0.4 2020 spring released OpenEye docking application employs chemgauss4 as a state-of-the-art scoring function, which includes the total scores of the favorable (shape, hydrogen bonding, and metal chelation) and unfavorable (desolvation and clash) interactions [34-37]. Finally, the results were displayed by the OpenEye VIDA-4.4.0 application [33].

\section{Conclusions}

In this study, new heterocycle-based 2-aminothiazole derivatives with amide functionalities were designed, synthesized, and biologically evaluated for their activity against PDE5. The amide group contributed to the formation of HB with the essential GLN:817:A. Compounds 2, 5, 10a, and 11b exhibited 100\% PDE5 inhibition compared to sildenafil utilizing the same dose. The effects of the compounds on MABP were also examined, and $10 \mathrm{a}$ and $11 \mathrm{~b}$ exerted significant inhibitory effects without severe hypotension. Compound $11 \mathrm{~b}$ slightly produced hypotension effect while compounds 5 and 10a increased the mean arterial blood pressure and may be attributed to the degree of selectivity toward different subtype and isoform of phosphodiesterase or maybe compounds 5 and 10a have an additional molecular mechanism beside the inhibition of phosphodiesterase enzyme in the blood vessel. This pushes us urgently to investigate the exact molecular mechanism of these two compounds in the blood vessels in the next work. These positive results are a cornerstone for the designs of more potent derivatives as PDE5 inhibitors for the safe treatment of ED.

Supplementary Materials: The following are available online, Molecular modeling investigation along with the copies of spectral data for the synthesized compounds are provided in the supplementary materials.

Author Contributions: Conceptualization, Y.A.M.M.E.; data curation, A.A.K., A.-B.A.E.-A., A.A.A., M.A.-R., M.I.A.H., and M.A.A.-S.; formal analysis, A.H.M.H., A.A.K., A.A.A., M.A.-R., M.I.A.H., and M.A.A.-S.; funding acquisition, A.B.; investigation, A.H.M.H., A.A.K., A.-B.A.E.-A., A.A.A., M.A.-R., M.I.A.H., and M.A.A.-S.; methodology, A.H.M.H., A.A.K., A.-B.A.E.-A., A.A.A., M.A.-R., M.I.A.H., and M.A.A.-S.; software, Y.A.M.M.E.; supervision, Y.A.M.M.E. and A.B.; visualization, Y.A.M.M.E.; writing —original draft, Y.A.M.M.E.; writing-review and editing, A.B. All authors have read and agreed to the published version of the manuscript.

Funding: The authors would like to extend their sincere appreciation to Researchers Supporting Project Number (RSP-2020/64), King Saud University, Riyadh, Saudi Arabia. 
Data Availability Statement: The data presented in this study are available in Supplementary Material.

Acknowledgments: The authors would like to extend their sincere appreciation to Researchers Supporting Project Number (RSP-2020/64), King Saud University, Riyadh, Saudi Arabia. The authors also would like to acknowledge the OpenEye scientific software for providing the academic license.

Conflicts of Interest: The authors declare no conflict of interest.

Sample Availability: Samples of the compounds 1-13 are available from the authors.

\section{References}

1. Beavo, J.A.; Conti, M.; Heaslip, R.J. Multiple cyclic nucleotide phosphodiesterases. Mol. Pharmacol. 1994, 46, 399-405. [PubMed]

2. Corbin, J.D.; Francis, S.H. Cyclic GMP Phosphodiesterase-5: Target of Sildenafil. J. Biol. Chem. 1999, 274, 13729-13732. [CrossRef]

3. Card, G.L.; England, B.P.; Suzuki, Y.; Fong, D.; Powell, B.; Lee, B.; Luu, C.; Tabrizizad, M.; Gillette, S.; Ibrahim, P.N.; et al. Structural Basis for the Activity of Drugs that Inhibit Phosphodiesterases. Structure 2004, 12, 2233-2247. [CrossRef]

4. Bank, D. Avanafil. Available online: https://www.drugbank.ca/drugs/DB06237 (accessed on 15 September 2020).

5. Beavo, J.A. Cyclic nucleotide phosphodiesterases: Functional implications of multiple isoforms. Physiol. Rev. 1995, 75, 725-748. [CrossRef]

6. Corbin, J.D. Mechanisms of action of PDE5 inhibition in erectile dysfunction. Int. J. Impot. Res. 2004, 16, S4-S7. [CrossRef] [PubMed]

7. Shaaban, M.A.; Radwan, A.A.; Mosa, Y.A.; Abd-Elwahab, B.A. Synthesis and Docking Study of Some Pyrazolo[3,4-d]Pyrimidin-4 (5H)-One Derivatives as Phosphodiesterase-5 Inhibitors. Saudi Pharm. 2009, 17, 109-129.

8. Tsai, C.-Y.; Kapoor, M.; Huang, Y.-P.; Lin, H.-H.; Liang, Y.-C.; Lin, Y.-L.; Huang, S.-C.; Liao, W.-N.; Chen, J.-K.; Huang, J.-S.; et al. Synthesis and Evaluation of Aminothiazole-Paeonol Derivatives as Potential Anticancer Agents. Mololecules 2016, $21,145$. [CrossRef]

9. Kesicki, E.A.; Bailey, M.A.; Ovechkina, Y.; Early, J.V.; Alling, T.; Bowman, J.; Zuniga, E.S.; Dalai, S.; Kumar, N.; Masquelin, T. Synthesis and evaluation of the 2-aminothiazoles as anti-tubercular agents. PLoS ONE 2016, 11, e0155209. [CrossRef]

10. Ghodse, S.M.; Telvekar, V.N. Synthesis of 2-aminothiazole derivatives from easily available thiourea and alkyl/aryl ketones using aqueous NaIC12. Tetrahedron Lett. 2015, 56, 472-474. [CrossRef]

11. Kayagil, I.; Demirayak, S. Synthesis and Anticancer Activities of Some Thiazole Derivatives. Phosphorus Sulfur Silicon Relat. Elem. 2009, 184, 2197-2207. [CrossRef]

12. Abouzeid, L.A.; El-Subbagh, H.I. DNA binding of ethyl 2-substituted aminothiazole-4-carboxylate analogues: A molecular modeling approach to predict their antitumor activity. Future J. Pharm. Sci. 2015, 1, 1-7. [CrossRef]

13. Ghasemi, B.; Najimi, M. Antibacterial effect of thiazole derivatives on Rhodoccocus equi, Brucella abortus, and Pasteurella multocida. Iranian J. Vet. Med. 2016, 10, 47-52.

14. Mishra, R.; Tomer, I.; Sharma, P.; Jha, K. Synthesis and antimicrobial evaluation of some novel thiazole derivatives. Der. Pharm. Sin. 2012, 3, 361-366.

15. Mishra, R.; Sharma, P.K.; Verma, P.K.; Tomer, I.; Mathur, G.; Dhakad, P.K. Biological Potential of Thiazole Derivatives of Synthetic Origin. J. Heterocycl. Chem. 2017, 54, 2103-2116. [CrossRef]

16. Hassan, F.A. Synthesis, characterization, anti-inflammatory, and antioxidant activities of some new thiazole derivatives. Int. J. Appl. Sci. Technol. 2012, 2, 180-187.

17. Lin, P.-Y.; Hou, R.-S.; Wang, H.-M.; Kang, I.-J.; Chen, L.-C. Efficient Synthesis of 2-Aminothiazoles and Fanetizole in Liquid PEG-400 at Ambient Conditions. J. Chin. Chem. Soc. 2009, 56, 455-458. [CrossRef]

18. Rodrigues, C.A.; Dos Santos, P.F.; Da Costa, M.O.L.; Pavani, T.F.A.; Xander, P.; Geraldo, M.M.; Mengarda, A.C.; De Moraes, J.; Rando, D.G. 4-Phenyl-1,3-thiazole-2-amines as scaffolds for new antileishmanial agents. J. Venom. Anim. Toxins Incl. Trop. Dis. 2018, 24, 26. [CrossRef]

19. Liu, Y.; Zhang, L.; Gong, J.; Fang, H.; Liu, A.; Du, G.; Xu, W. Design, synthesis, and biological activity of thiazole derivatives as novel influenza neuraminidase inhibitors. J. Enzym. Inhib. Med. Chem. 2010, 26, 506-513. [CrossRef] [PubMed]

20. Hussein, A.H.M.; Khames, A.A.; El-Adasy, A.-B.A.; Atalla, A.A.; Abdel-Rady, M.; Hassan, M.I.A.; Nemr, M.T.M.; Elshaier, Y.A.M.M. Design, synthesis and biological evaluation of new 2-aminothiazole scaffolds as phosphodiesterase type 5 regulators and COX-1/COX-2 inhibitors. RSC Adv. 2020, 10, 29723-29736. [CrossRef]

21. Zoraghi, R.; Corbin, J.D.; Francis, S.H. Phosphodiesterase-5 Gln817 Is Critical for cGMP, Vardenafil, or Sildenafil Affinity its orientation impacts cGMP but not cAMP affinity. J. Biol. Chem. 2006, 281, 5553-5558. [CrossRef] [PubMed]

22. Zoraghi, R.; Francis, S.H.; Corbin, J.D. Critical Amino Acids in Phosphodiesterase-5 Catalytic Site That Provide for High-Affinity Interaction with Cyclic Guanosine Monophosphate and Inhibitors. Biochemistry 2007, 46, 13554-13563. [CrossRef]

23. Hussein, A.H.M.; El-Adasy, A.-B.A.; Khames, A.A.; Atalla, A.A.; Abdel-Rady, M.; El-Adasy, A.P.A.-B.A.; Khames, A.P.A.A. 3-Oxobutanamides in Heterocyclic Synthesis, Synthesis Approaches for new Pyridines, Pyrimidines and their Fused Derivatives. ChemistrySelect 2017, 2, 1625-1629. [CrossRef] 
24. Price, C.P.; Grzesiak, A.L.; Kampf, J.W.; Matzger, A.J. Maize 1: A Trimorphic Azo Pigment. Cryst. Growth Des. 2003, 3, 1021-1025. [CrossRef]

25. Hussein, A.H.M.; Gad-Elkareem, M.A.M.; El-Adasy, A.-B.A.A.M.; Khames, A.A.; Othman, I.M.M. $\beta$-Oxoanilides in Heterocyclic Synthesis: Synthesis and Antimicrobial Activity of Pyridines, Pyrans, Pyrimidines and Azolo, Azinopyrimidines Incorporating Antipyrine Moiety. Int. J. Org. Chem. 2012, 2, 341-351. [CrossRef]

26. Folkers, K.; Harwood, H.; Johnson, T.B. Researches on pyrimidines. Cxxx. Synthesis of 2-keto-1, 2, 3, 4-tetrahydropyrimidines. J. Am. Chem. Soc. 1932, 54, 3751-3758. [CrossRef]

27. Spoto, G.; Berardi, S.; Ajerba, G.; De Laurentiis, V. A reverse-phase HPLC method for cyclic nucleotide phosphodiesterases activity and classification. In Purine and Pyrimidine Metabolism in Man VIII; Springer: Boston, MA, USA, 1995; Volume 370, pp. 815-820.

28. OpenEye Lead Optimization EON. Available online: https://www.eyesopen.com/eon (accessed on 12 October 2020).

29. Wang, H.; Liu, Y.; Huai, Q.; Cai, J.; Zoraghi, R.; Francis, S.H.; Corbin, J.D.; Robinson, H.; Xin, Z.; Lin, G. Multiple Conformations of Phosphodiesterase-5 implications for enzyme function and drug development. J. Biol. Chem. 2006, 281, 21469-21479. [CrossRef]

30. OpenEye Database Preparation. Filter. Available online: https://www.eyesopen.com/filter (accessed on 5 October 2020).

31. McGann, M. FRED Pose Prediction and Virtual Screening Accuracy. J. Chem. Inf. Model. 2011, 51, 578-596. [CrossRef]

32. OpeEye Fast Rigid Exhaustive Docking (FRED) Receptor, Version 2.2.5; OpenEye Scientific Software: Santa Fe, NM, USA. Available online: http:/ / www.eyesopen.com (accessed on 15 October 2020).

33. OpenEye Scientific Software: OEApplications 2020.2. Available online: https://docs.eyesopen.com/applications (accessed on 25 December 2020).

34. Ahmed, M.S.; Kopel, L.C.; Halaweish, F. Structural Optimization and Biological Screening of a Steroidal Scaffold Possessing Cucurbitacin-Like Functionalities as B-Raf Inhibitors. Chem. Med. Chem. 2014, 9, 1361-1367. [CrossRef]

35. Elshaier, Y.A.; Shaaban, M.A.; El Hamid, M.K.A.; Abdelrahman, M.H.; Abou-Salim, M.A.; Elgazwi, S.M.; Halaweish, F. Design and synthesis of pyrazolo[3,4- d ]pyrimidines: Nitric oxide releasing compounds targeting hepatocellular carcinoma. Bioorganic Med. Chem. 2017, 25, 2956-2970. [CrossRef] [PubMed]

36. Noolvi, M.N.; Patel, H. A comparative QSAR analysis and molecular docking studies of quinazoline derivatives as tyrosine kinase (EGFR) inhibitors: A rational approach to anticancer drug design. J. Saudi Chem. Soc. 2013, 17, 361-379. [CrossRef]

37. Prasad, V.R.; Reddy, G.D.; Kathmann, I.; Amareswararao, M.; Peters, G. Nitric oxide releasing acridone carboxamide derivatives as reverters of doxorubicin resistance in MCF7/Dx cancer cells. Bioorganic Chem. 2016, 64, 51-58. [CrossRef] [PubMed] 